\title{
What lures cross-border venture capital inflows?
}

\author{
Andrea Schertler ${ }^{\mathrm{a}, \mathrm{b}, *}$, Tereza Tykvováa ${ }^{\mathrm{c}, \mathrm{d}}$ \\ ${ }^{a}$ Nord/LB Chair of Integrated Financial Risk Management, Leuphana University, Scharnhorststr. 1, 21335 Lüneburg, Germany \\ ${ }^{\mathrm{b}}$ Rijksuniversiteit Groningen, Department of Economics, Econometrics \& Finance, The Netherlands \\ ${ }^{\mathrm{c}}$ Chair of Corporate Finance, Hohenheim University, Wollgrasweg 23, 7059-9 Stuttgart, Germany \\ ${ }^{\mathrm{d}}$ ZEW Mannheim, Department of International Finance and Financial Management, Germany
}

\section{JEL classification:}

F21

G24

\section{Keywords:}

Venture capital

Internationalization

Gross and net cross-border inflows

Economic factors

\section{A B S T R A C T}

We investigate if economic factors drive gross and net cross-border venture capital inflows differently. Using a dataset of venture capital investments in European and North American countries from 2000 to 2008, we find that higher expected economic growth goes hand in hand with higher gross as well as net inflows, while higher market capitalization and a more favorable environment for venture capital intermediation entail higher gross inflows, but lower net inflows. The latter two findings may suggest that crossborder venture capital inflows partly compensate for potential limits in domestic venture capital supply. However, the findings may also reflect that venture capitalists' locational decisions depend on the viability of capital markets.

(c) 2012 Elsevier Ltd. All rights reserved.

\section{Introduction}

The change in the business model of venture capitalists from investing locally toward investing across borders began to intensify in the late 1990s (Aizenman and Kendall, 2008). Nowadays venture capitalists from one country invest abroad and at the same time portfolio companies located in this country receive funding from foreign venture capitalists. At least two lines of argument exist for why venture capitalists invest across borders. First, by crossing borders, venture capitalists exploit differences in risk-adjusted expected returns between their home country and the portfolio companies' countries. The higher risk-adjusted expected returns of cross-border investments have to outweigh

\footnotetext{
* Corresponding author. Nord/LB Chair of Integrated Financial Risk Management, Leuphana University, Scharnhorststr. 1, 21335 Lüneburg, Germany. Tel.: +49 41316772147.

E-mail addresses: schertler@leuphana.de (A. Schertler), Tereza.Tykvova@uni-hohenheim.de (T. Tykvová).
} 
transaction and information costs, which are likely to be higher for cross-border investments than for domestic investments (e.g., Wright et al., 2005; Cumming and Johan, 2007). Transaction and information costs arise because venture capital is typically invested in opaque, risky ventures where information asymmetries between the entrepreneurs and the venture capitalists are particularly pronounced. Therefore, these investments require intensive pre-investment screening, postinvestment hands-on management support and control (e.g., Amit et al., 1998). Second, venture capitalists invest abroad because of deal flow considerations and value-adding activities. By jointly investing in deals, venture capitalists spread their limited funds over a larger number of deals, and may generate additional value through the combination of several venture capitalists' skill sets, experience and networks. The literature has investigated this argument for national syndication. Since in many cross-border deals domestic venture capitalists syndicate with foreign partners, this mechanism may also be at work in cross-border flows.

This paper investigates whether economic factors drive gross and net cross-border venture capital flows differently. While the recent literature has studied economic factors of gross venture capital flows, i.e. investments that venture capitalists originate in foreign countries (e.g., Aizenman and Kendall, 2008; Schertler and Tykvová, 2011), it has not yet investigated net flows that take into account that countries originate and receive cross-border venture capital finance at the same time. Our paper fills this gap. We expect that some economic factors affect gross and net inflows differently, since deal flow considerations and value-adding activities likely shape gross inflows but not net inflows, which may be driven primarily by expected return differences. Within a simple demand-supply framework, which we augment to a two-country case, we argue that an increase in an economic factor which more strongly affects supply than demand reduces net inflows. Thus, countries with a high value in an economic factor which primarily affects supply and less so demand are expected to have lower net inflows than countries with a low value in this factor. On the contrary, we expect that an increase in this economic factor leads to higher gross inflows, because the country offers foreign venture capitalists more opportunities to syndicate. Thus, a country with a high value in the respective economic factor is expected to have higher gross inflows than a country with a low value.

We introduce two new measures, another contribution of our paper to the recent literature on venture capital internationalization. The first measure captures the fact that venture capitalists do not raise funds every year, and that they invest raised funds over several years. Therefore, we investigate how excess funds (more raised funds relative to investments) affect gross and net cross-border flows. The second measure we introduce is an indicator of the tax and legal environment for venture capital intermediation. It combines information on funds' structure regulation and regulations related to retaining talent in fund management companies. We borrow other economic factors, such as stock market capitalization and expected economic growth, from the recent literature on domestic venture capital investments (e.g., Jeng and Wells, 2000; Allen and Song, 2005; Romain and van Pottelsberghe, 2004; Da Rin et al., 2006; Armour and Cumming, 2006) and gross cross-border activity (Aizenman and Kendall, 2008; Guler and Guillén, 2010a,b; Schertler and Tykvová, 2011).

With a country-pair dataset of venture capital investments and cross-border flows in 15 European and two North American countries ${ }^{1}$ from 2000 to 2008, we investigate if economic factors in a country shape this country's gross inflows (outflows) and net inflows (outflows) differently. Gross inflows in country $i$ from country $k$ are the investments that portfolio companies located in country $i$ receive from venture capitalists located in country $k$, while gross outflows of country $i$ to $k$ are the investments that venture capitalists located in $i$ invest in portfolio companies located in $k$. We define net inflows in country $i$ from $k$ as the gross inflows minus gross outflows. ${ }^{2}$ If net inflows are positive, a country receives more venture capital finance from abroad than it originates there. Net outflows are equal to

\footnotetext{
${ }^{1}$ We only focus on countries with non-negligible domestic venture capital activity. Other research has focused on less developed venture capital industries. For example, Groh and von Lichtenstein (2009) develop a composite measure of economic factors to investigate strengths and weaknesses of Central Eastern European countries in attracting international venture capital finance.

2 Our definition of net cross-border flows differs from the one used in other studies on cross-border equity flows. Portes and Rey (2005), for example, focus on changes in portfolio positions, and calculate net cross-border flows as securities' purchases of $k$-country companies by $i$-country citizens minus securities' sales of $k$-country companies by $i$-country citizens.
} 
minus net inflows. We find that two economic factors shape gross and net inflows differently. A higher stock market capitalization and a more favorable environment for venture capital intermediation come along with higher gross inflows, but with lower net inflows. The former results can be explained by deal flow considerations and value-adding activities, the latter by expected return differences. Higher expected growth goes hand in hand with higher gross as well as net inflows. With respect to gross and net outflows, we do not find pronounced differences: higher capitalization and a more favorable environment for venture capital intermediation in a country come along with higher gross as well as net outflows from this country, higher expected growth goes hand in hand with lower gross as well as net outflows.

Investigating whether economic factors affect gross and net cross-border flows differently is interesting to academics since it improves our understanding of the internationalization process in venture capital finance. In addition, it is also interesting to policy makers given the prominent role of venture capital finance for a country's economic progress, since venture capital finance is supposed to positively affect economic growth, employment, innovative activity, and company performance (for a recent survey, see Strömberg, 2009). The international dimension in venture capital finance makes public policy much more complex, as policy actions not only affect investments by domestic venture capitalists in domestic and foreign companies, but also foreign venture capitalists' participation in this particular country. Therefore, public policy aiming at fostering local venture capital industries has to take into account the internationalization in venture capital finance. From a policy perspective, net inflows are much more relevant than gross inflows because net inflows provide insights into how much more capital a country attracts from abroad than it originates there.

The remainder of the paper is organized as follows. Section 2 employs a simple neoclassical supplydemand framework as a tool to predict the direction of net cross-border venture capital inflows. It also discusses why some economic factors may shape gross and net cross-border inflows differently. Section 3 describes the dataset. Section 4 investigates which economic factors drive gross and net flows. Section 5 summarizes our main findings and concludes.

\section{Theoretical considerations}

The literature puts forward two lines of argument for cross-border venture capital activity: expected return differences on the one hand and deal flow considerations and value-adding activities on the other hand. While gross venture capital flows are certainly affected by both, net flows will be influenced primarily by expected return differences. Therefore, we expect some economic factors to shape gross and net flows in different ways. In the following, we first use a simple neoclassical supplydemand model of a closed economy that we augment to a two-country setting in order to study how expected return differences initiate net inflows. We then discuss deal flow considerations and valueadding activities as an explanation for why venture capitalists invest across borders. This will help us understand gross inflows and outflows.

\subsection{Expected return differences}

In a closed economy venture capital demand results from companies' need to finance investment projects with positive net present values. When the risk-adjusted expected return (hereafter referred to as expected return) required by the limited partners, such as pension funds and insurance companies, increases, the aggregate demand for venture capital decreases because fewer projects will have positive net present values. Thus, the demand curve is downward sloping, as in Panel a of Fig. 1. Venture capital supply in a closed economy stems from the willingness of limited partners to invest in this asset class, as well as from the availability of general partners with resources (in particular human capital) to set up and manage venture capital funds. There are at least two reasons why a higher quantity supplied has to go along with higher expected returns. First, when the capital gains of limited partners are subject to non-unique tax rates, higher-taxed investors provide capital for venture capital funds only if they are compensated with a higher expected return (Gompers and Lerner, 1998). Second, since general partners need particular expertise to identify and structure promising deals, and since building up such expertise is costly and requires time, the number of qualified general partners will 


\section{Panel a - Domestic investments (one-country setting)}

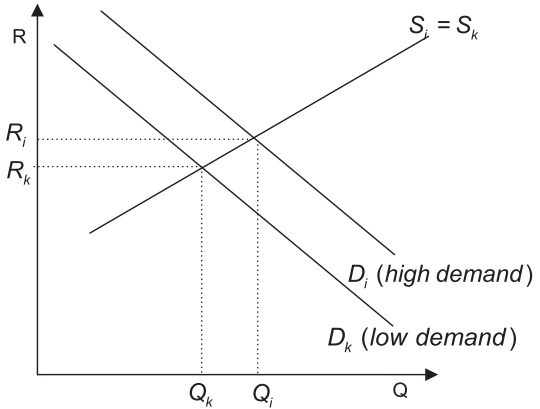

High and low demand

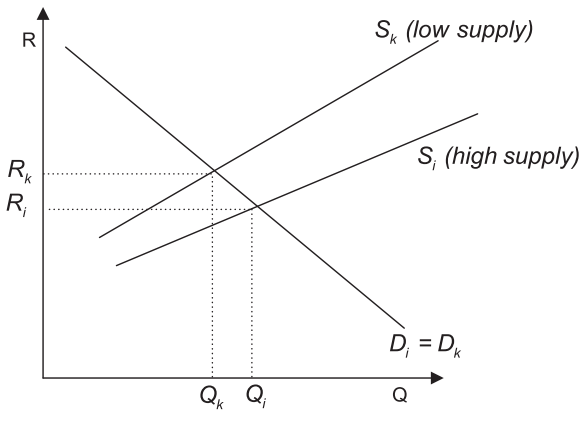

High and low supply

Panel $b$ - Cross-border investments and demand differences (two-country setting)

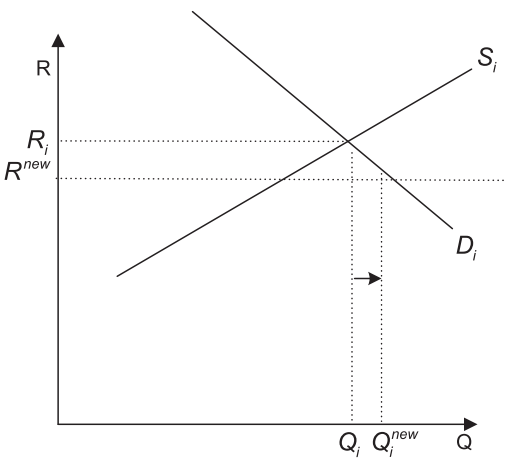

Country $i$ : high demand

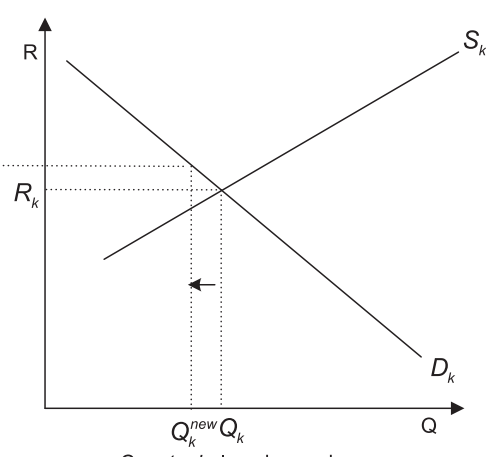

Country $k$ : low demand

Panel c-Cross-border investments and supply differences (two-country setting)

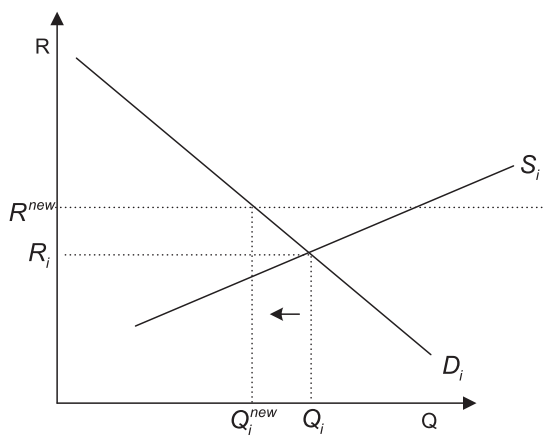

Country $i$ : High supply

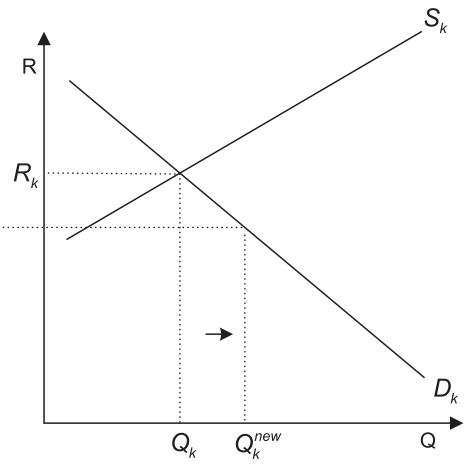

Country $k$ : Low supply

Fig. 1. Domestic and cross-border investments. Panel a shows how differences in supply and demand conditions in a closed economy determine the quantity of venture capital finance, $Q$ and the risk-adjusted expected return, $R$, in equilibrium. Panel b (Panel c) shows the impact of differences in the demand (supply) on cross-border investments in a two-country setting. 
only increase when expected return rises. Therefore, the supply curve is upward sloping, as in Panel a of Fig. 1. The intersection of the aggregate demand and supply curves determines the expected return and the quantity of venture capital finance in equilibrium in a closed economy.

The recent literature has identified economic factors that shape domestic investments; most of them likewise shift both the aggregate demand and supply curves. As shown in Panel a of Fig. 1, a shift in the demand curve from low to high implies, ceteris paribus, a higher expected return (left picture), while a shift in the supply curve from low to high implies a lower expected return in the new equilibrium (right picture). Stock market development is an example of a factor that influences both demand and supply. A viable stock market positively affects demand because it gives entrepreneurs the opportunity to enter into an implicit contract on control with venture capitalists. While the entrepreneurs' control is diluted after a trade sale, an initial public offering (IPO) offers them the chance to partially reacquire control, since they can obtain leading management positions in listed companies (Black and Gilson, 1998; Bascha and Walz, 2002). A viable stock market is also supportive of supply because it allows venture capitalists to build up a reputation by successfully exiting from their portfolio companies via an IPO. Venture capitalists may profit from this reputation by raising funds from limited partners at more favorable conditions in the future (Gompers, 1996). Other factors shaping both demand and supply are technological creativeness and expected growth. Higher technological creativeness (Ueda and Hirukawa, 2008) and expected growth (Armour and Cumming, 2006; Gompers and Lerner, 1998; Cumming and MacIntosh, 2006) come along with more entrepreneurs who demand venture capital finance to start up their companies. They may also influence supply since they affect inter alia the availability of qualified fund managers. Another important factor is taxation. Capital gains tax rates influence the decision to become an entrepreneur and thus demand (Poterba, 1989). The position of the supply curve also depends on capital gains tax rates (see, Keuschnigg and Nielsen, 2002, 2004) and other elements of the fiscal environment relevant for venture capital intermediation, such as VAT on carried interest and management fees or the availability of a tax-transparent fund structure. High taxes on carried interest and management fees may destroy the general partners' incentives to select, monitor and support portfolio companies. Finally, the legal framework affects valuations and returns (Cumming and Walz, 2010), the quality of support that the venture capitalists offer their portfolio companies (Bottazzi et al., 2009), the structure of contracts and deal characteristics (Lerner and Schoar, 2004), and the efficiency of project screening and deal origination (Cumming et al., 2010).

While we do not aim at identifying demand and supply factors in cross-border flows, we believe that augmenting the simple demand-supply model of a closed economy to a two-country framework is useful to understand net inflows. In our model, we assume that the two countries are identical apart from either demand or supply. To exemplify what may drive net flows, let country $i$ have a higher demand than country $k$. This case is illustrated in Panel b of Fig. 1. In the absence of cross-border flows, the expected return is higher in $i$ (left picture) than in $k$ (right picture). The positive expected return difference between countries $i$ and $k$, caused by differences in economic factors shaping demand, incentivizes venture capitalists from country $k$ to invest in country $i$. In the absence of distorting factors, such as transaction and information costs, the expected returns would equalize in the new equilibrium in both countries. However, distorting factors cannot be neglected in the context of venture capital. A venture capitalist would invest abroad when a higher expected return abroad, relative to domestic investments, outweighs the costs, which are likely to be higher for cross-border than for domestic investments (e.g., Wright et al., 2005; Cumming and Johan, 2007). As a result, the between-country return difference may decrease if cross-border flows take place, but is unlikely to disappear completely.

Now, let country $i$, but not country $k$, have a favorable environment for supply. This case is illustrated in Panel c of Fig. 1. Without cross-border flows, the expected return is higher in country $k$ (right picture) than in country $i$ (left picture). The difference in supply conditions generates an expected return difference that encourages cross-border flows from country $i$ to $k$. One may argue that this case is not relevant because smart general partners find a way to create an appropriate fund structure in a country with an unfavorable environment. Then expected return difference may be insufficient to encourage flows from country $i$ to $k$. However, the environment for the supply of venture capital may also affect the general partners' location decision (Chen et al., 2010). General partners may locate in countries with a favorable environment for venture capital supply. Setting up a fund in a country that offers a favorable environment reduces costs, since it requires less creativeness, money and time than 
creating a vehicle under a poor environment. For example, a favorable tax environment for venture capital intermediation in country $i$, such as low VAT on carried interest and management fees, may not only motivate venture capitalists located in country $i$ to invest in country $k$. It may, in addition, induce potential general partners from country $k$ to set up their funds in country $i$ and then invest in $k$. Thus, net cross-border inflows might arise when general partners decide not to set up a fund in their home country but in a country with a favorable environment and then invest in their home country.

Accordingly, economic factors increasing demand in country $i$ lead to higher net inflows that country $i$ attracts from abroad, while economic factors that positively affect the supply in country $i$ decrease net inflows. These theoretical considerations are, however, of limited use since most economic factors are expected to shape both aggregate demand and supply. But in our simple framework, we can still determine the direction in which an economic factor influencing both demand and supply affects net inflows. ${ }^{3}$ As long as an economic factor affects demand more strongly than supply, an increase in the factor increases net inflows in this country. On the opposite, an increase in an economic factor that affects supply more strongly than demand decreases net inflows in that country.

\subsection{Deal flows and value adding}

Expected return differences may not be able to explain why we observe inflows and outflows in a country at the same time. The existing literature puts forward several other explanations for why venture capitalists invest abroad (e.g., Mäkelä and Maula, 2006; Bruner and Chaplinsky, 2002; Ribeiro and De Carvalho, 2008; Dixit and Jayaraman, 2001; Wright et al., 2005; Manigart et al., 2006). These explanations are based on the characteristic features of venture capital financing. In the following we summarize two explanations for why venture capitalists may invest abroad even if there is no expected return difference.

Venture capitalists may invest across borders to diversify their limited funds geographically in order to reduce unsystematic risk. Limited partners do not necessarily prefer geographical diversification at the venture capital funds' level because diversification already takes place at the level of their portfolios. However, because of asymmetric information between general partners and their limited partners, general partners may have a vested interest in diversifying investments. They may prefer a more diversified fund than their limited partners because their knowledge and capital is bound to the fund, and because they care about negative fund performance. Such negative performance could constitute a bad signal of their capabilities to limited partners, who would then be reluctant to provide new money when the general partners raise their next funds.

Another explanation is built on the observation that in a large part of cross-border investments domestic and foreign venture capitalists syndicate. Venture capitalists share deals with each other since they can then split up their limited funds over a larger number of portfolio companies. Financing a deal jointly may not only serve as a diversification tool to the general partner. Syndication may also give rise to additional value through the combination of information, experience, networks, and skill sets of several venture capitalists, from which limited partners profit as well. For example, domestic venture capitalists have better information about the company and the local environment than their foreign partners. Foreign venture capitalists offer complementary skills, such as their familiarity with capital and product markets in their home countries. These skills may be particularly valuable to portfolio companies planning an expansion into product or capital markets outside their home countries. The advantages of having both a domestic and a foreign venture capitalist on board might be reflected in a better performance of these portfolio companies (e.g., Devigne et al., 2011; Dai et al., in press). Limited partners then benefit from these higher returns. Therefore, we expect that economic

\footnotetext{
3 The demand and supply curves in country $y \in\{i, k\}$ are given by: $R_{y}=A_{y}-b Q_{y}^{\mathrm{D}}$ and $R_{y}=C_{y}+d Q_{y}^{S}$ with $d$ and $b>0$. Country $i$ has a favorable environment, while $k$ has a less favorable environment. A favorable environment leads to higher demand and supply: $A_{i}=A_{k}+L^{\mathrm{D}}$ and $C_{i}=C_{k}-L^{\mathrm{S}}$, where $L^{\mathrm{D}}$ is the demand curve shift and $L^{\mathrm{S}}$ the supply curve shift. For the equilibrium return without cross-border flows we obtain $R_{y}^{*}=\left(d A_{y}+b C_{y}\right) /(d+b)$. A positive expected return difference between countries $i$ and $k$ requires $L^{\mathrm{D}}>(b / d) L^{\mathrm{S}}$. Whenever $b>d$, a positive expected return difference between $i$ and $k$ implies that the demand shift is larger than the supply shift.
} 
factors which stimulate domestic investments positively affect gross cross-border inflows, since more investments by domestic venture capitalists in a country result in more opportunities for foreign venture capitalists to syndicate and finance deals in this country.

The above discussion leads us to the conclusion that some economic factors indeed influence gross and net inflows differently. We expect an increase in an economic factor stimulating demand and/or supply to increase gross inflows. Thus, a country with a high value in an economic factor that stimulates domestic investments is expected to have higher gross inflows than a country with a low value in this economic factor. To the contrary, we expect that an increase in an economic factor which is more strongly related to supply than to demand reduces net cross-border inflows this country attracts from any other country. Thus, a country with a high value in an economic factor stimulating supply more strongly than demand is expected to have lower net inflows than a country with a low value in this economic factor.

\section{The data}

\subsection{Data on venture capital investments}

Our dataset contains domestic and cross-border venture capital investments in 15 European countries, the United States, and Canada from 2000 to 2008. This dataset stems from Zephyr database, offered by Bureau van Dijk Electronic Publishing. This information platform, which initially aimed at M\&A transactions, also conveys IPO and venture capital transaction data. Recently, researchers working in the field of venture capital and private equity have started to work with these data (e.g., Bloom et al., 2009; Brav et al., 2009; Beuselinck et al., 2009; Goossens et al., 2008; Abdesselam et al., 2008; Prijcker et al., 2009). Besides the names of the portfolio company and all investors, Zephyr contains a wide range of information on the participating parties, such as their countries of origin, information on parent companies, detailed business descriptions and industry affiliations. ${ }^{4}$

In our dataset we include deals from the Zephyr database that fulfill the following conditions. (i) The deal has one of the following types of financing: venture capital, private equity, angel investment, corporate venturing, or seed financing. (ii) The portfolio company is a non-financial company located in Europe or North America. (iii) The investors acquire a minority stake in the portfolio company. Thus, we do not consider buy-out transactions. (iv) At least one investor from Europe or North America provides venture capital. To distinguish venture capitalists from other investors, we analyzed investors' business descriptions and retained only those deals in which the business description of at least one investor included the terms "venture capital" or "private equity". In some cases, the identity of the investor in Zephyr is indicated on the fund level, in other cases on the level of the venture capital company. In the case of dependent private equity companies, sometimes the parent company, in other cases the subsidiary is indicated as the investor in a particular deal. We created a consistent pattern by using the information on the ultimate parent of the venture capitalist. ${ }^{5}$ This procedure changed the relevant information on venture capitalists, such as the country of origin, in only 3 percent of the cases.

\footnotetext{
${ }^{4}$ The recent literature also compares this database to other databases. The Zephyr coverage of the number of deals seems to be slightly inferior, while the information on deal volume seems to be superior to Thomson VentureXpert (e.g., Schertler and Tykvová, 2011), which is the most widely used database in venture capital research. A comparison with aggregate figures, such as the ones published by the European Venture Capital Association, is not possible for several reasons. For instance, EVCA statistics display investment amounts, i.e., the amount of money invested in companies, while Zephyr reports deal volumes including the investment amounts plus payments to selling shareholders.

${ }^{5}$ However, a noteworthy characteristic is that parent company information in Zephyr is updated regularly. To outline the drawback of using this information let investor A buy a share in the portfolio company $Z$ on January 1 st, 2004. If another investor B took over investor A on January 1st, 2003, we would correctly attribute the above-mentioned deal to B, because B became A's parent before the transaction had been conducted. However, if B took over A on January 1st, 2005, we would falsely assign this deal to B based on the parent information offered by Zephyr. To correct this "mistake" we have checked (within the Zephyr deal database) whether venture capitalists merged or were acquired during our observation period. All deals before a merger or acquisition date (in the example January $1 \mathrm{st}, 2005$ ) have been assigned to the original investor, all deals after this date to its parent company.
} 
Besides a simple deal count, we also employ the aggregate investment volume. For approximately 80 percent of the deals, Zephyr delivers information on the total deal volume, which is the total amount invested in the portfolio company plus the amount eventually paid to selling shareholders. We approximate missing deal volumes by predicted volumes from a linear regression model using the deal and the deal-country characteristics as RHS variables. More specifically, we include dummy variables for the country and the year of the deal, the industry affiliation of the portfolio company as well as the number of venture capitalists that participated in the deal. Almost all variables are significantly correlated with the deal volume. However, the explanatory power of the regression is moderate, with an adjusted $R^{2}$ of about 30 percent.

We were obliged to make some assumptions to aggregate cross-border flows at the country-pair level since many venture capital deals are syndicated across borders. As to the deal number, as long as all venture capitalists participating in a deal are located in one country each deal counts once. A deal counts more than once if investors from different countries, e.g., the United Kingdom and France, invest in a portfolio company located outside their home countries, e.g., in Germany. This deal appears once in the deal count between the United Kingdom and Germany and once in the deal count between France and Germany. As to the investment volume, we divided the deal volume by the number of venture capitalists and assigned the partial deal volume to the respective country pair. In the above example, half the deal volume is assigned to flows between the United Kingdom and Germany, the other half to flows between France and Germany.

For each of the 17 sample countries and each country-pair combination, Table 1 displays the full spectrum of our dataset by showing the volume of domestic investments, gross inflows, and gross outflows. The volumes of gross inflows and outflows between the country pairs in our sample indicate the importance of exchanging investment opportunities among venture capitalists and they reveal some interesting patterns. Some countries have investment links with many other countries, while others have only one or a few investment links. For example, venture capitalists located in the United Kingdom and the United States originate deals in all other countries under focus and portfolio companies located in these two countries receive venture capital financing from all other countries. Some regional clusters do, however, also exist: For instance, Austrian venture capitalists invest intensively in German portfolio companies, and Finnish venture capitalists are actively involved in Swedish portfolio companies.

Table 1 also gives some insight into net flows. Several of the countries in our sample have higher total gross outflows than gross inflows. For instance, Germany, Switzerland, the United Kingdom and the United States originate much larger investment volumes abroad than they attract from there. France and Italy, among others, have higher inflows than outflows and thus attract venture capital finance from foreign venture capitalists. Noteworthy, some of the countries with high inflows but low outflows, such as France ( $€ 27.3$ bn gross inflows and only $€ 6.3$ bn gross outflows), do not have positive net inflows from all other countries. For example, French portfolio companies receive $€ 3.2$ bn more from Belgian venture capitalists than French venture capitalists invest in Belgian portfolio companies (net inflows are positive), while French portfolio companies receive $€ 553$ million less from Italian venture capitalists than French venture capitalists invest in Italian portfolio companies (net inflows are negative).

\subsection{Dependent and RHS variables}

In our analyses we use gross inflows, gross outflows and net inflows for annual country-pair observations. We first aggregate gross inflows and gross outflows for each country pair and year in our sample. We normalize both gross inflows and outflows by country-pair GDP, which is the average GDP of the venture capitalist's and the portfolio company's countries, since the countries in our sample vary substantially in size. This normalization eliminates a bias toward findings of positive relationships between investments and economic factors purely based on country size. Since the normalized gross flows are positively skewed (for example, the skewness is 4.6 for the normalized gross outflow volume), we additionally use a log transformation (e.g., Dahl and Shrieves, 1999). Net inflows are the difference between normalized and log-transformed gross inflows and gross outflows. Panel a of Table 2 gives 
Table 1

Venture capital investment data (in million Euros).

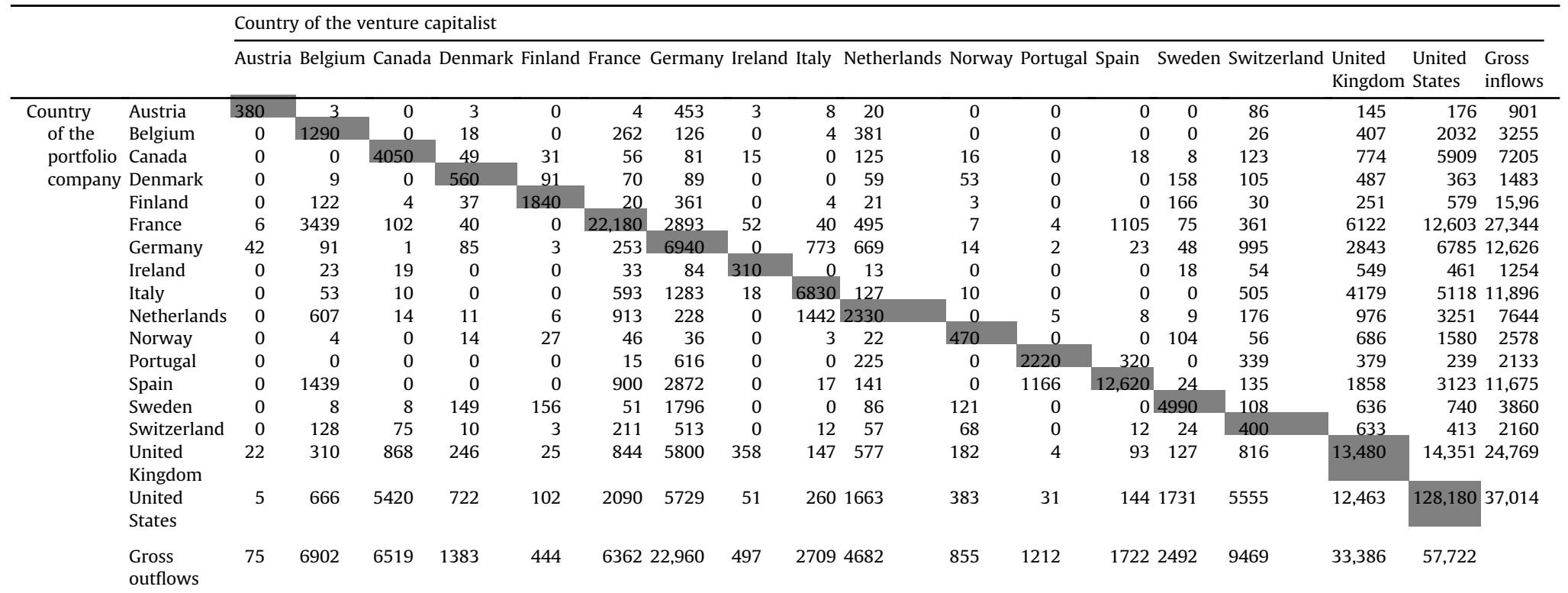

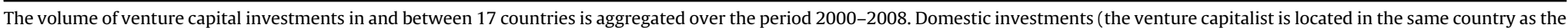

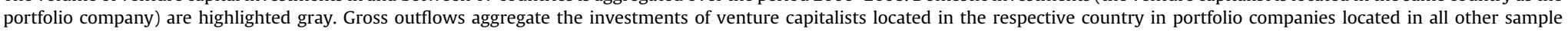

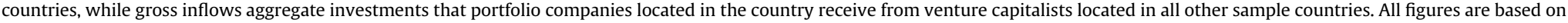
the Zephyr database. 
Table 2

Summary statistics and correlations.

\begin{tabular}{|c|c|c|c|c|c|c|c|c|c|c|}
\hline \multicolumn{11}{|c|}{ Panel $a$-Summary statistics } \\
\hline & & \multirow{2}{*}{ Mean } & $\begin{array}{l}\text { Standard } \\
\text { deviation }\end{array}$ & \multicolumn{7}{|c|}{ Description } \\
\hline \multicolumn{10}{|c|}{ Dependent variables (country-pair data) } & \\
\hline \multicolumn{11}{|c|}{ Gross flows } \\
\hline \multicolumn{2}{|c|}{ Number } & 0.69 & 0.91 & \multicolumn{7}{|c|}{$\begin{array}{l}\log (1+\text { number of flows normalized by average } \\
\text { country-pair GDP in trillion Euros })\end{array}$} \\
\hline \multicolumn{2}{|c|}{ Volume } & 1.50 & 1.86 & \multicolumn{7}{|c|}{$\begin{array}{l}\log (1+\text { volume of flows normalized by average } \\
\text { country-pair GDP in million Euros })\end{array}$} \\
\hline \multicolumn{11}{|c|}{ Net flows } \\
\hline \multicolumn{2}{|c|}{ Number } & 0.00 & 0.86 & \multicolumn{7}{|c|}{ Number of gross inflows minus number of gross outflows } \\
\hline \multicolumn{2}{|c|}{ Volume } & 0.00 & 1.90 & \multicolumn{7}{|c|}{ Volume of gross inflows minus volume of gross outflows } \\
\hline \multicolumn{11}{|c|}{ RHS variables (country data) } \\
\hline \multicolumn{2}{|c|}{ Capitalization } & 0.986 & 0.609 & \multicolumn{7}{|c|}{$\begin{array}{l}\text { Stock market capitalization relative to GDP. } \\
\text { Source: www.worldbank.org }\end{array}$} \\
\hline \multicolumn{2}{|c|}{ Patents } & 3.639 & 2.454 & \multicolumn{7}{|c|}{$\begin{array}{l}\text { Number of patents granted to residents relative } \\
\text { to the country's GDP in billion Euros. Source: } \\
\text { www.wipo.int/ipstats/fr/statistics/patents; } \\
\text { www.worldbank.org }\end{array}$} \\
\hline \multicolumn{2}{|c|}{ Expected growth } & 0.025 & 0.009 & \multicolumn{7}{|c|}{$\begin{array}{l}\text { Expected growth of real GDP over next 3-5 years. } \\
\text { Source: Thomson Financial Datastream }\end{array}$} \\
\hline \multicolumn{2}{|c|}{ Returns } & 0.106 & 0.286 & \multicolumn{7}{|c|}{$\begin{array}{l}\text { Annual stock market returns from MSCI performance } \\
\text { indexes in Euros. Source: Thomson Financial Datastream }\end{array}$} \\
\hline \multicolumn{2}{|c|}{ Lack funds } & 0.190 & & \multicolumn{7}{|c|}{$\begin{array}{l}\text { Dummy variable equal to } 1 \text { if the funding gap is larger } \\
\text { than } 10 \% \text {. The funding gap is } 3 \text {-year average investment/ } \\
\text { 3-year average fundraising minus } 1 ; 0 \text { otherwise. Source: } \\
\text { EVCA yearbooks, NVCA yearbooks }\end{array}$} \\
\hline \multicolumn{2}{|c|}{ Excess funds } & 0.235 & & $\begin{array}{l}\text { Dun } \\
\text { than } \\
3 \text {-ye } \\
\text { EVC }\end{array}$ & $\begin{array}{l}\text { my vari } \\
-40 \% . \mathrm{T} \\
\text { ar avera. } \\
\text { A yearbo }\end{array}$ & $\begin{array}{l}\text { ble equal } \\
\text { ee fundin } \\
\text { e fundrai } \\
\text { ks, NVCA }\end{array}$ & $\begin{array}{l}\text { gap is } 3- \\
\text { ing minu } \\
\text { yearbook }\end{array}$ & $\begin{array}{l}\text { funding } \\
\text { fear aver } \\
1 ; 0 \text { othe }\end{array}$ & $\begin{array}{l}\text { ap is sma } \\
\text { ge invest } \\
\text { rwise Sou }\end{array}$ & $\begin{array}{l}\text { ler } \\
\text { nent/ } \\
\text { ce: }\end{array}$ \\
\hline $\mathrm{VC}$ in & dicator & 2.211 & 0.430 & $\begin{array}{l}\text { Tota } \\
\text { indi } \\
\text { from } \\
\text { Higl } \\
200\end{array}$ & $\begin{array}{l}\text { score o } \\
\text { ator bet } \\
\text { the EVC } \\
\text { er value } \\
\text { i }\end{array}$ & $\begin{array}{l}\text { EVCA Ber } \\
\text { veen } 200 \\
\text { A Benchm } \\
\text { of indicat }\end{array}$ & $\begin{array}{l}\text { chmarkin } \\
\text { and } 200 \\
\text { arking Re } \\
r \text { is bette }\end{array}$ & $\begin{array}{l}\text { Reports } \\
(2003-0 \\
\text { ort 2003 } \\
\text { Source: }\end{array}$ & $\begin{array}{l}\text { The valu } \\
\text {; 2006-0 } \\
\text { (2004; } 20 \\
\text { EVCA, } 20\end{array}$ & $\begin{array}{l}\text { of the } \\
\text { 3) comes } \\
\text { o6). } \\
3,2004 \text {, }\end{array}$ \\
\hline VC-st & pply indicator & 2.600 & 0.457 & $\begin{array}{l}\text { Subs } \\
\text { tran } \\
\text { man } \\
\text { rest } \\
\text { indi }\end{array}$ & $\begin{array}{l}\text { core fror } \\
\text { sparency } \\
\text { agement } \\
\text { ictions, } t \\
\text { ator is b }\end{array}$ & $\begin{array}{l}\text { the EVC } \\
\text { for dome } \\
\text { fees and } \\
\text { xation of } \\
\text { tter. Soul }\end{array}$ & $\begin{array}{l}\text { Benchm } \\
\text { tic invest } \\
\text { arried int } \\
\text { carried in } \\
\text { ce: EVCA, }\end{array}$ & $\begin{array}{l}\text { rking Re } \\
\text { rs, ability } \\
\text { rest, free } \\
\text { erest. Hi } \\
003,200\end{array}$ & $\begin{array}{l}\text { orts inclu } \\
\text { to avoid } \\
\text { dom from } \\
\text { her value } \\
4,2006\end{array}$ & $\begin{array}{l}\text { ding tax } \\
\text { IAT on } \\
\text { undue } \\
\text { of }\end{array}$ \\
\hline Good & VC-supply indicator & 0.471 & & $\begin{array}{l}\text { Dun } \\
\text { take } \\
200\end{array}$ & $\begin{array}{l}\text { Imy vari } \\
\text { s on the } \\
\text {, } 2006\end{array}$ & $\begin{array}{l}\text { ble equal } \\
\text { highest va }\end{array}$ & $\begin{array}{l}\text { to } 1 \text { wher } \\
\text { ue; } 0 \text { oth }\end{array}$ & $\begin{array}{l}\text { the VC-s } \\
\text { rwise. So }\end{array}$ & $\begin{array}{l}\text { lpply indi } \\
\text { urce: EVC }\end{array}$ & ator \\
\hline Bad & C-supply indicator & 0.098 & & $\begin{array}{l}\text { Dun } \\
\text { take } \\
\text { EVC }\end{array}$ & $\begin{array}{l}\text { Imy varia } \\
\text { s on one } \\
\text { A, } 2003 \text {, }\end{array}$ & $\begin{array}{l}\text { ble equal } \\
\text { of the two } \\
004,200\end{array}$ & $\begin{array}{l}1 \text { wher } \\
\text { lowest v }\end{array}$ & $\begin{array}{l}\text { the VC-s } \\
\text { ues; } 0 \text { ot }\end{array}$ & $\begin{array}{l}\text { Ipply indi } \\
\text { herwise. }\end{array}$ & $\begin{array}{l}\text { ator } \\
\text { ource: }\end{array}$ \\
\hline Panel & $b$ - Correlations & & & & & & & & & \\
\hline & & (1) & $(2)$ & (3) & $(4)$ & $(5)$ & $(6)$ & (7) & (8) & (9) \\
\hline (1) & Capitalization & 1 & & & & & & & & \\
\hline (2) & Patents & 0.11 & 1 & & & & & & & \\
\hline (3) & Expected growth & 0.03 & $0.14^{*}$ & 1 & & & & & & \\
\hline (4) & Returns & $0.14^{*}$ & 0.07 & $0.33^{*}$ & 1 & & & & & \\
\hline (5) & Lack funds & $-0.21^{*}$ & -0.09 & $-0.16^{*}$ & 0.02 & 1 & & & & \\
\hline (6) & Excess funds & $0.36^{*}$ & 0.12 & $0.26^{*}$ & 0.01 & $-0.27^{*}$ & 1 & & & \\
\hline (7) & VC indicator & $0.26^{*}$ & -0.13 & 0.12 & -0.02 & -0.07 & $0.37^{*}$ & 1 & & \\
\hline (8) & VC-supply indicator & $0.41^{*}$ & 0.07 & $0.24^{*}$ & 0.02 & $-0.23^{*}$ & $0.24^{*}$ & $0.56^{*}$ & 1 & \\
\hline (9) & Good VC-supply indicato & $0.24^{*}$ & $0.14^{*}$ & $0.31^{*}$ & 0.02 & $-0.22^{*}$ & $0.22 *$ & $0.53^{*}$ & $0.83^{*}$ & 1 \\
\hline (10) & Bad VC-supply indicator & $-0.24^{*}$ & -0.09 & -0.01 & 0.00 & $0.18^{*}$ & -0.08 & $-0.31^{*}$ & $-0.70^{*}$ & $-0.31^{*}$ \\
\hline
\end{tabular}


Table 2 (continued)

\begin{tabular}{|c|c|c|c|c|}
\hline \multicolumn{5}{|c|}{ Panel $c$ - Mean VC indicators by countries } \\
\hline & VC indicator & $\begin{array}{l}\text { VC-supply } \\
\text { indicator }\end{array}$ & $\begin{array}{l}\text { Good VC-supply } \\
\text { indicator }\end{array}$ & $\begin{array}{l}\text { Bad VC-supply } \\
\text { indicator }\end{array}$ \\
\hline Austria & 1.77 & 1.67 & 0.00 & 0.67 \\
\hline Belgium & 2.18 & 2.47 & 0.00 & 0.00 \\
\hline Canada & 3.00 & 3.00 & 1.00 & 0.00 \\
\hline Denmark & 2.10 & 2.60 & 0.00 & 0.00 \\
\hline Finland & 1.85 & 2.73 & 0.33 & 0.00 \\
\hline France & 2.22 & 2.47 & 0.33 & 0.00 \\
\hline Germany & 1.69 & 2.20 & 0.00 & 0.00 \\
\hline Ireland & 2.54 & 3.00 & 1.00 & 0.00 \\
\hline Italy & 2.15 & 2.33 & 0.00 & 0.00 \\
\hline Netherlands & 2.28 & 3.00 & 1.00 & 0.00 \\
\hline Norway & 1.93 & 3.00 & 1.00 & 0.00 \\
\hline Portugal & 2.05 & 2.07 & 0.00 & 0.33 \\
\hline Spain & 2.12 & 1.93 & 0.00 & 0.67 \\
\hline Sweden & 1.91 & 3.00 & 1.00 & 0.00 \\
\hline Switzerland & 2.09 & 2.73 & 0.33 & 0.00 \\
\hline United Kingdom & 2.69 & 3.00 & 1.00 & 0.00 \\
\hline United States & 3.00 & 3.00 & 1.00 & 0.00 \\
\hline
\end{tabular}

Summary statistics of dependent variables are based on country-pair data. Summary statistics of RHS variables and their correlations as well as mean VC indicators are based on country data of 17 European and North American countries. The mean of net flows is based on 272 country pairs and equals zero since net inflows from country $i$ to $k$ equal the negative net inflows from country $k$ to $i$. ${ }^{*}$ denotes significance at the 10 percent level.

summary statistics and definitions of our dependent and RHS variables, and Panel b depicts correlations between RHS variables.

Four of our RHS variables have previously been used in the literature on domestic investments (e.g., Jeng and Wells, 2000; Gompers and Lerner, 1998) and gross cross-border investments (e.g., Aizenman and Kendall, 2008; Schertler and Tykvová, 2011). We first employ stock market capitalization to assess the viability of the financial markets. Second, to capture the technological creativeness of a country, we use patent counts. We normalize these size-sensitive RHS variables by GDP. We, third, include expected economic growth and, fourth, stock market returns to proxy the investment environment in a country.

We employ two new sets of variables that we expect to affect gross and net flows. Our first set captures the relation between a country's investments and fundraising. We collected fundraising and investment data on venture capitalists located in each country from venture capital and private equity associations. Then we calculated a fundraising gap, defined as the difference between a country's investment and its fundraising normalized by its fundraising. Since venture capitalists do not raise funds every year and since they invest raised funds over several years, we used the moving-average investments and fundraising over a three-year horizon instead of annual numbers. Interestingly and noteworthy, this fundraising gap varies from -60 percent to more than 130 percent, indicating that venture capitalists invest more than they raise in some countries and periods, while they raise more than they invest in other countries and periods.

Because the funding gap shows clusters, is much dispersed and contains outliers, we do not use this gap itself as an RHS variable, but we create two dummy variables. The first dummy variable, which we call lack funds, equals one if the funding gap is larger than 10 percent. We choose a cut-off level of 10 percent to ensure that the lack of funds is substantially large and that the number of observations for which the dummy variable equals 1 is not too small. A total of 19.0 percent of the observations in our sample are classified as having a lack of funds. The interpretation of this variable might be the following: Countries with a lack of funds might be seen as running short of funds; therefore gross outflows from these countries might be lower than those from other countries. The second dummy variable, which we call excess funds, equals one if the funding gap is smaller than -40 percent. We choose a cut-off level of -40 percent to capture a severe excess of funds and, at the same time, this cutoff level ensures that the number of observations for which the dummy variable equals 1 is not too small. A total of 23.5 percent of the country-year observations in our sample are classified as having 
excess funds. Venture capitalists located in countries with excess funds might experience greater pressure or have stronger intentions to find investment opportunities at home and abroad, thus leading to larger gross outflows. Of our country-year observations, 42.5 percent are classified as having a balanced investment-fundraising relation.

The second set of variables which we expect to affect gross and net flows is related to tax and legal factors. Following Armour and Cumming (2006), we use an indicator of the tax and legal environment pertinent to venture capital demand and supply. This VC indicator comes from the Benchmarking Tax and Legal Environments Reports conducted by the European Private Equity and Venture Capital Association (EVCA) that were published in 2003, 2004, and 2006. The total score value from these reports combines information on (i) the quality of the tax and legal environment for general and limited partners, (ii) the environment for the portfolio companies, such as fiscal R\&D incentives for contracting researchers and technology transfer, and (iii) the environment for retaining talents in portfolio companies and venture capital funds. This indicator combines many facets of the tax and legal environment in a single figure for each country and year, while other studies focus on particular fiscal variables, such as the capital gains taxation (e.g., Da Rin et al., 2006; Gompers and Lerner, 1998) and/or various more general legal variables (Cumming and Walz, 2010; Bottazzi et al., 2009; Lerner and Schoar, 2004; Cumming et al., 2010). We do not use these general tax and legal indicators because they capture economy-wide characteristics, whereas our VC indicator particularly focuses on the tax and legal environment relevant for venture capital activity. In Panel c of Table 2, we depict the VC indicator for the countries in our sample. A higher value indicates a more favorable environment.

Besides this general VC indicator, we construct a new indicator that can be attributed to venture capital supply only. This VC-supply indicator only includes information on the "fund structure" and "retaining talent in fund management companies" from the Benchmarking Reports, i.e., we omit factors that affect demand for venture capital. More specifically, the VC-supply indicator contains the following items: (i) Tax transparency for domestic investors: A fund structure is called tax transparent if the fund is not subject to taxation and taxation only applies at the limited partners' level after gains and revenues have been distributed. The availability of a transparent fund structure is likely to play a decisive role because a tax on funds' income diminishes the return to investors. The item takes on a high value if the country has established a tax-transparent investment vehicle structure and a low value otherwise. (ii) The ability to avoid VAT on management fees: The management fee is an annual management charge received by the fund's management company. The item takes on a high value if the management fee is not subject to VAT and a low value otherwise. (iii) The ability to avoid VAT on carried interest: Carried interest, which typically constitutes 20 percent of the fund's profits, is usually rendered payable when the limited partners have received repayment plus a minimum required rate of return (hurdle rate). The item takes on a high value if carried interest is exempted from VAT and a low value otherwise. (iv) Freedom from undue restrictions: The item takes on a high value if no restrictions severely affect venture capitalists' investment decisions, while it takes on a low value when regulations restrict investment decisions in a negative way. (v) Taxation of carried interest: The item has a high value if carried interest is taxed as capital gains, it has a medium value if carried interest is taxed as dividends, and it has a low value if carried interest is taxed as income. Our VCsupply indicator averages these five items; a higher value of our indicator implies a more favorable tax and legal environment for venture capital intermediation. Panel c of Table 2 shows that the VC indicator and the VC-supply indicator differ substantially for several countries: Scandinavian countries have a medium climate for venture capital activity, as indicated by the mean VC indicator around 2 , while they have a favorable climate for venture capital intermediation, as indicated by the mean VC-supply indicator of 3 or nearly 3.

Since the VC-supply indicator only takes on five different values between 1.4 and 3 with a sample mean of 2.6, we also use an alternative classification. We distinguish between countries with a good, medium and bad VC-supply indicator and employ dummy variables instead of the VC-supply indicator. The first dummy variable, good VC-supply indicator, equals one if the VC-supply indicator takes on the highest value in our sample. Of the country-year observations in our sample, 47 percent are classified as having a good environment for venture capital intermediation. The second dummy variable, bad VCsupply indicator, equals 1 if the VC-supply indicator takes on one of the two lowest values in our sample. Only about 10 percent of the country-year observations in our sample are classified as having a poor 
environment for venture capital intermediation. The remaining 43 percent with one of the two medium values of the VC-supply indicator represent the omitted category. As the VC-supply indicator takes on five different values, we are limited in our choice of alternative cut-off levels for the bad and good VC-supply indicator.

\section{Empirical analyses}

To test whether economic factors affect gross and net cross-border flows differently, we use country-pair data. Since we have 17 countries in our sample, we end up with 272 country pairs $(17 \times 16)$. With a sample period of nine years (2000-2008) we obtain 2448 country-pair-year observations. We start by presenting results from univariate tests, and then discuss results from multivariate analyses for which we carry out several robustness tests. These tests also include an alternative approach built on country-level data.

\subsection{Univariate tests}

In order to conduct the univariate tests, for each RHS variable (except dummy variables), we split the country-pair-year sample into those country-pair-years in which this variable is above the sample population median and those country-pair-years in which this variable is below the median. We then test whether the average number and volume of cross-border flows differ between these two subsamples. These tests help us to understand the relevance of economic factors for cross-border flows. Comparing the test statistics for gross inflows (outflows) with those for net inflows (outflows) allows us to gain first insights into whether economic factors play a different role for gross and net flows. Table 3 delivers the results.

Regarding inflows, two of the six economic factors (stock market capitalization and VC-supply indicator) seem to be related to gross inflows with a different sign than to net inflows (in both number and volume). Countries with an above-median capitalization have higher gross inflows but lower net inflows than countries with a below-median capitalization. Countries with high capitalization attract more cross-border investments, but they seem to originate even more investments abroad than countries with low capitalization. Hence, the influence of capitalization differs fundamentally between gross and net inflows. Similarly, we find that the VC-supply indicator affects gross

Table 3

Tests on equality of means.

\begin{tabular}{|c|c|c|c|c|c|c|c|c|c|}
\hline \multirow{2}{*}{$\begin{array}{l}\text { Economic } \\
\text { factors }(X)\end{array}$} & \multicolumn{3}{|c|}{ Mean number of gross inflows } & \multicolumn{3}{|c|}{ Mean number of gross outflows } & \multicolumn{3}{|c|}{ Mean number of net inflows } \\
\hline & $\begin{array}{l}X> \\
\text { median }\end{array}$ & $\begin{array}{l}X> \\
\text { median }\end{array}$ & $\begin{array}{l}\text { Mean } \\
\text { test }\end{array}$ & $\begin{array}{l}X> \\
\text { median }\end{array}$ & $\begin{array}{l}X> \\
\text { median }\end{array}$ & $\begin{array}{l}\text { Mean } \\
\text { test }\end{array}$ & $\begin{array}{l}X> \\
\text { median }\end{array}$ & $\begin{array}{l}X> \\
\text { median }\end{array}$ & $\begin{array}{l}\text { Mean } \\
\text { test }\end{array}$ \\
\hline \multicolumn{10}{|c|}{ Panel $a$-Investment number } \\
\hline Capitalization & 0.84 & 0.54 & $8.16^{* * *}$ & 0.94 & 0.44 & $14.17^{* * *}$ & -0.10 & 0.10 & $-5.94^{* * *}$ \\
\hline Patents & 0.72 & 0.66 & $1.77^{*}$ & 0.70 & 0.68 & 0.50 & 0.02 & 0.02 & 1.34 \\
\hline Expected growth & 0.73 & 0.65 & $2.16^{* *}$ & 0.63 & 0.75 & $-3.42^{* * *}$ & 0.10 & -0.11 & $5.92^{* * *}$ \\
\hline Returns & 0.68 & 0.69 & -0.44 & 0.65 & 0.73 & $-2.00^{* *}$ & 0.03 & -0.03 & $1.66^{*}$ \\
\hline VC indicator & 0.72 & 0.66 & $1.77^{*}$ & 0.71 & 0.67 & 1.31 & 0.01 & -0.01 & 0.49 \\
\hline VC-supply indicator & 0.80 & 0.59 & $5.51^{* * *}$ & 0.84 & 0.55 & $8.00^{* * *}$ & -0.05 & 0.04 & $-2.57^{* *}$ \\
\hline \multicolumn{10}{|c|}{ Panel $b$-Investment volume } \\
\hline Capitalization & 1.78 & 1.21 & $7.71^{* * *}$ & 2.03 & 0.96 & $14.71^{* * *}$ & -0.24 & 0.24 & $-6.40^{* * *}$ \\
\hline Patents & 1.60 & 1.40 & $2.64^{* * *}$ & 1.59 & 1.40 & $2.47^{* *}$ & 0.01 & -0.01 & 0.16 \\
\hline Expected growth & 1.52 & 1.47 & 0.60 & 1.35 & 1.66 & $-4.01^{* * *}$ & 0.17 & -0.18 & $4.50^{* * * *}$ \\
\hline Returns & 1.49 & 1.51 & -0.19 & 1.41 & 1.59 & $-2.48^{* *}$ & 0.09 & -0.09 & $2.24^{* *}$ \\
\hline VC indicator & 1.63 & 1.37 & $3.51^{* * *}$ & 1.61 & 1.39 & $2.95^{* * *}$ & 0.02 & -0.02 & 0.54 \\
\hline VC-supply indicator & 1.65 & 1.36 & $3.90^{* * *}$ & 1.82 & 1.21 & $8.15^{* * *}$ & -0.17 & 0.14 & $-4.15^{* * *}$ \\
\hline
\end{tabular}

Mean tests of whether venture capital cross-border flows of countries for which the economic factor is above the sample median differ from the ones of countries for which it is below the median. Mean tests are based on country-pair-year observations with unequal variances. All variables are defined in Table 2 . We use the lagged values of all factors, except for expected growth. ${ }^{* * *},{ }^{* *}$, and ${ }^{*}$ denote significance at the 1,5 , and 10 percent level, respectively. 
and net inflows differently. Countries with a poor environment for venture capital intermediation receive lower gross inflows but higher net inflows than countries with a favorable environment. Thus, countries with a poor environment for venture capital intermediation, which probably have less developed venture capital industries, attract net inflows from other countries, which probably have plenty of venture capitalists. Most of the other economic factors do not differ substantially and consistently in their influence on gross and net inflows. Some economic factors (such as patent counts) only influence gross inflows, while others (such as stock market returns) only affect net inflows. Expected growth shapes gross and net inflows in a similar way. Countries with an above-median expected growth have higher gross as well as net inflows than countries with a below-median expected growth, although the gross investment volume lacks significance.

When we compare the effects of economic factors in a country on this country's gross and net outflows, we do not find any significant difference. Countries in which capitalization exceeds the sample median originate significantly more gross and net outflows than countries whose capitalization is below the sample median. In addition, countries whose expected growth and stock market returns are above the respective sample medians originate significantly less gross and net outflows than countries whose values are below the sample median. This might indicate that venture capitalists located in countries with high expected growth and stock returns invest more intensely at home. The environment for venture capital intermediation also affects how much venture capital finance a country originates abroad. Countries with an above-median VC-supply indicator originate significantly more gross and net outflows than countries with a below-median VC-supply indicator.

\subsection{Multivariate analyses}

In Table 4 we present estimation results on how economic factors in a country affect the number and volume of gross inflows (Columns (1)-(3)), gross outflows (Columns (4)-(6)) and net inflows (Columns (7)-(9)). We use three alternative model specifications with respect to the inclusion of indicators for the environment for venture capital activity: In Columns (1), (4), and (7) we employ the VC indicator, in Columns (2), (5), and (8) we use the VC-supply indicator, and in Columns (3), (6), and (9) we rely on the dummy variables good and bad VC-supply indicator. To minimize potential endogeneity of our RHS variables, we use their lagged values, except for expected growth. We include year dummy variables and we add a full set of country dummy variables to account for the economic factors in the venture capitalists' countries (Columns (1)-(3) and (7)-(9)), or the portfolio companies' countries (Columns (4)-(6)). ${ }^{6}$ Since we have 17 countries in our sample, we include 16 country dummy variables; reference country is the United States.

Gross inflows and gross outflows increase, while net inflows decrease (less investments are attracted than are originated) when the stock market capitalization of the country under focus increases. Thus, countries with high capitalization have higher gross inflows and gross outflows but attract lower net inflows than countries with low capitalization. When capitalization increases by onestandard deviation (which is 0.609 , see Panel a of Table 2), the volume of gross inflows (normalized by GDP and log-transformed) in Column (1) rises by 0.21 . Given that the average volume of gross inflows is 1.50 with a standard deviation of 1.86 , the effect is economically remarkable. When capitalization increases by one-standard deviation, the volume of net inflows decreases by 0.34 . This effect is also economically remarkable since the average volume of net inflows is zero with a standard deviation of 1.90 .

Patent counts come along with higher gross inflows and gross outflows, but do not influence net inflows. The coefficients on patents in the gross inflow regressions are similar to those in the gross outflow regressions. Therefore, patents do not have a significant impact on net inflows; the only exception is found in Column (8) of Panel b, but this effect is only significant at the $10 \%$ level. These findings might be surprising because patents are seen as a demand factor and should therefore lead to

\footnotetext{
${ }^{6}$ These country dummy variables control for all time-invariant characteristics of the venture capitalist's country, such as the law tradition. Kaplan et al. (2007), for instance, demonstrate that when investing abroad, deal contracts of venture capitalists located in civil law countries differ significantly from those of investors located in common law countries.
} 
Table 4

Economic factors and cross-border flows.

\begin{tabular}{|c|c|c|c|c|c|c|c|c|c|}
\hline & (1) & (2) & (3) & (4) & (5) & (6) & (7) & $(8)$ & (9) \\
\hline & \multicolumn{3}{|l|}{ Gross inflows } & \multicolumn{3}{|l|}{ Gross outflows } & \multicolumn{3}{|l|}{ Net inflows } \\
\hline \multicolumn{10}{|c|}{ Panel $a$-Investment number } \\
\hline Capitalization & $0.221(0.028)^{* * *}$ & $0.190(0.030)^{* * *}$ & $0.210(0.029)^{* * *}$ & $0.572(0.032)^{* * *}$ & $0.502(0.034)^{* * *}$ & $0.520(0.033)^{* * * *}$ & $-0.351(0.036)^{* * *}$ & $-0.312(0.039)^{* * *}$ & $-0.309(0.037)^{* * * *}$ \\
\hline Patents & $0.048(0.007)^{* * *}$ & $0.041(0.007)^{* * * *}$ & $0.038(0.007)^{* * *}$ & $0.039(0.007)^{* * * *}$ & $0.035(0.007)^{* * * *}$ & $0.030(0.007)^{* * * *}$ & $0.009(0.007)$ & $0.006(0.007)$ & $0.008(0.007)$ \\
\hline $\begin{array}{l}\text { Expected } \\
\text { growth }\end{array}$ & $0.553(1.733)$ & $-1.003(1.785)$ & $-0.247(1.833)$ & $-6.130(1.845)^{* * *}$ & $-9.018(1.927)^{* * *}$ & $-8.505(1.988)^{* * *}$ & $6.683(1.889)^{* * * *}$ & $8.014(1.955)^{* * * *}$ & $8.258(1.997)^{* * *}$ \\
\hline Returns & $-0.023(0.087)$ & $-0.040(0.087)$ & $-0.052(0.086)$ & $-0.264(0.092)^{* * *}$ & $-0.213(0.092)^{* *}$ & $-0.213(0.090)^{* *}$ & $0.241(0.084)^{* * *}$ & $0.173(0.083)^{* *}$ & $0.161(0.082)^{* *}$ \\
\hline Lack funds & $-0.127(0.036)^{* * *}$ & $-0.094(0.036)^{* * *}$ & $-0.086(0.036)^{* *}$ & $-0.072(0.042)^{*}$ & $-0.028(0.041)$ & $-0.006(0.042)$ & $-0.055(0.042)$ & $-0.067(0.042)$ & $-0.080(0.042)^{*}$ \\
\hline Excess funds & $-0.160(0.046)^{* * *}$ & $-0.089(0.041)^{* *}$ & $-0.083(0.041)^{* *}$ & $-0.310(0.048)^{* * *}$ & $-0.277(0.043)^{* * *}$ & $-0.269(0.044)^{* * *}$ & $0.150(0.047)^{* * * *}$ & $0.188(0.043)^{* * * *}$ & $0.187(0.043)^{* * * *}$ \\
\hline VC indicator & $0.224(0.043)^{* * *}$ & & & $0.120(0.045)^{* * *}$ & & & $0.104(0.044)^{* * *}$ & & \\
\hline $\begin{array}{l}\text { VC-supply } \\
\text { indicator }\end{array}$ & & $0.201(0.037)^{* * * *}$ & & & $0.281(0.037)^{* * *}$ & & & $-0.080(0.040)^{* *}$ & \\
\hline Good VC-supply & & & $0.100(0.036)^{* * *}$ & & & $0.173(0.039)^{* * * *}$ & & & $-0.073(0.038)^{*}$ \\
\hline Bad VC-supply & & & $-0.186(0.048)^{* * *}$ & & & $-0.301(0.043)^{* * * *}$ & & & $0.115(0.048)^{* *}$ \\
\hline $\begin{array}{l}\text { No. of } \\
\quad \text { observations }\end{array}$ & 2448 & 2448 & 2448 & 2448 & 2448 & 2448 & 2448 & 2448 & 2448 \\
\hline$F$-test & $61.1^{* * *}$ & $56.4^{* * * *}$ & $55.1^{* * *}$ & $31.0^{* * * *}$ & $32.2^{* * *}$ & $33.3^{* * *}$ & $16.3^{* * * *}$ & $16.4^{* * *}$ & $16.1^{* * * *}$ \\
\hline Adjusted $R^{2}$ & 0.35 & 0.35 & 0.35 & 0.24 & 0.26 & 0.26 & 0.20 & 0.20 & 0.20 \\
\hline \multicolumn{10}{|c|}{ Panel $b$ - Investment volume } \\
\hline Capitalization & $0.348(0.053)^{* * *}$ & $0.360(0.060)^{* * *}$ & $0.378(0.057)^{* * *}$ & $1.013(0.064)^{* * *}$ & $0.918(0.069)^{* * * *}$ & $0.942(0.066)^{* * * *}$ & $-0.665(0.073)^{* * *}$ & $-0.557(0.080)^{* * *}$ & $-0.564(0.075)^{* * *}$ \\
\hline Patents & $0.114(0.012)^{* * *}$ & $0.094(0.012)^{* * *}$ & $0.089(0.012)^{* * *}$ & $0.135(0.014)^{* * *}$ & $0.120(0.014)^{* * *}$ & $0.108(0.014)^{* * *}$ & $-0.021(0.015)$ & $-0.025(0.014)^{*}$ & $-0.019(0.014)$ \\
\hline $\begin{array}{l}\text { Expected } \\
\text { growth }\end{array}$ & $-6.966(3.575)^{*}$ & $-7.595(3.788)^{* *}$ & $-6.964(3.830)^{*}$ & $-20.73(3.914)^{* * *}$ & $-25.25(4.123)^{* * *}$ & $-24.45(4.219)^{* * *}$ & $13.766(4.251)^{* * *}$ & $17.654(4.482)^{* * *}$ & $17.489(4.519)^{* * *}$ \\
\hline Returns & $-0.078(0.152)$ & $-0.253(0.153)^{*}$ & $-0.256(0.152)^{*}$ & $-0.590(0.179)^{* * *}$ & $-0.609(0.180)^{* * *}$ & $-0.597(0.177)^{* * *}$ & $0.512(0.170)^{* * *}$ & $0.355(0.168)^{* *}$ & $0.341(0.166)^{* *}$ \\
\hline Lack funds & $-0.017(0.083)$ & $0.030(0.083)$ & $0.050(0.082)$ & $-0.032(0.090)$ & $0.057(0.087)$ & $0.110(0.087)$ & $0.015(0.104)$ & $-0.028(0.103)$ & $-0.061(0.103)$ \\
\hline Excess funds & $-0.302(0.085)^{* * *}$ & $-0.071(0.077)$ & $-0.063(0.077)$ & $-0.435(0.096)^{* * *}$ & $-0.267(0.087)^{* * *}$ & $-0.251(0.088)^{* * *}$ & $0.133(0.095)$ & $0.196(0.089)^{* *}$ & $0.188(0.090)^{* * *}$ \\
\hline VC indicator & $0.693(0.080)^{* * *}$ & & & $0.538(0.092)^{* * *}$ & & & $0.155(0.094)^{*}$ & & \\
\hline $\begin{array}{l}\text { VC-supply } \\
\text { indicator }\end{array}$ & & $0.266(0.078)^{* * * *}$ & & & $0.547(0.074)^{* * * *}$ & & & $-0.281(0.088)^{* * *}$ & \\
\hline Good VC-supply & & & $0.155(0.070)^{* *}$ & & & $0.350(0.079)^{* * *}$ & & & $-0.195(0.083)^{* *}$ \\
\hline Bad VC-supply & & & $-0.289(0.112)^{* * *}$ & & & $-0.649(0.091)^{* * * *}$ & & & $0.360(0.117)^{* * *}$ \\
\hline $\begin{array}{l}\text { No. of } \\
\quad \text { observations }\end{array}$ & 2448 & 2448 & 2448 & 2448 & 2448 & 2448 & 2448 & 2448 & 2448 \\
\hline F-test & $79.6^{* * *}$ & $70.0^{* * *}$ & $68.3^{* * *}$ & $37.7^{* * *}$ & $37.8^{* * *}$ & $40.1^{* * *}$ & $15.4^{* * *}$ & $15.9^{* * * *}$ & $15.7^{* * * *}$ \\
\hline Adjusted $R^{2}$ & 0.40 & 0.39 & 0.39 & 0.25 & 0.25 & 0.26 & 0.19 & 0.19 & 0.19 \\
\hline
\end{tabular}

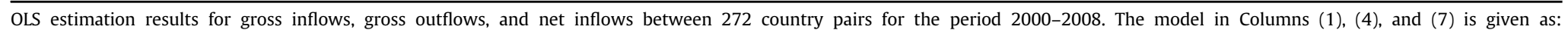

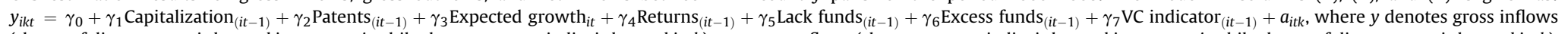

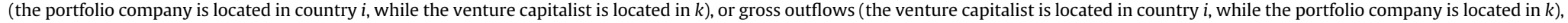

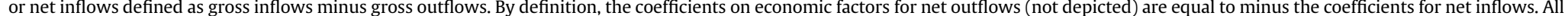

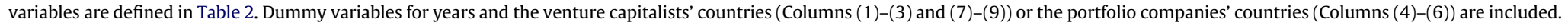
White (1980)-heteroscedasticity-consistent standard errors are given in parentheses. ${ }^{* * *}{ }^{* *}$, and ${ }^{*}$ denote significance at the 1,5 , and 10 percent level, respectively. 
higher gross as well as net inflows. Especially the strong and positive effect of patents on gross outflows needs further explanation. This positive effect might arise because a viable venture capital industry will develop only in countries with many innovative companies that seek finance. Hence countries with more patents will have a better developed venture capital industry and will originate more transactions abroad than countries with lower patent counts. In this sense, patent counts may determine the "long-run" equilibrium number of venture capitalists active in a country.

Expected growth and stock market returns do not shape gross inflows significantly. We will further investigate this surprising finding in the robustness section. Gross outflows depend negatively on expected growth and stock market returns. Thus, higher expected growth and stock market returns may imply that venture capitalists invest more at home and less abroad. Higher expected growth and stock market returns come along with higher net inflows. The volume of net inflows increases by 0.12 and 0.15 for a one-standard deviation increase in expected growth and returns, respectively.

Surprisingly, countries with a lack of funds have lower gross inflows and in one specification they even have lower net inflows (Column (9)) than countries with a balanced investment-fundraising relation. Hence, a lack of funds seems not to capture the availability of venture capital. Rather it may capture venture capitalists' expectations on available investment opportunities in a country. When venture capitalists expect a decline in investment opportunities, they will raise fewer funds and hence the country is classified as having a lack of funds. At the same time the decline in investment opportunities leads to lower gross as well as net inflows. Countries with excess funds have lower gross inflows and gross outflows, but higher net inflows than countries without excess funds. The effect of excess funds might reflect venture capitalists' capabilities to predict improved future investment opportunities for which they raise funds in advance. Then, domestic venture capitalists less often invite foreign venture capitalists to participate as syndication partners in a transaction, which explains the negative effect of excess funds on gross inflows. At the same time, countries with excess funds as an indicator for an increase in investment opportunities attract more investments from abroad than they originate there.

A more favorable environment for venture capital activity comes along with higher gross inflows, gross outflows, and net inflows (Columns (1), (4), and (7)). The VC-supply indicator influences gross inflows and gross outflows positively, and it affects net inflows negatively (Columns (2), (5), and (8)). Hence, countries with a favorable environment for venture capital intermediation originate and attract more deals abroad than countries with a poor environment. In addition, countries with a favorable environment for venture capital intermediation originate more deals than they attract, while countries with a poor environment attract more deals than they originate. Finally, we see that countries with a good VC-supply indicator have significantly higher gross inflows and gross outflows, and at the same time significantly lower net inflows, while countries with a bad VC-supply indicator have significantly lower gross inflows and gross outflows, and at the same time significantly higher net inflows than countries with a medium VC-supply indicator (Columns (3), (6), and (9)).

To sum up, we do observe significant sign changes for two economic factors in our inflow regressions: capitalization and the VC-supply indicator shape gross and net inflows in a quite different way. To the contrary, for gross and net outflows, we find that economic factors in a country shape them quite similarly. We only observe that the VC indicator affects gross outflows positively and net outflows negatively.

\subsection{Robustness tests}

The results presented so far are preliminary in the sense that we have not considered all data specificities. In this section, we perform four types of robustness tests to check whether taking these specificities into account changes our findings. We provide selected results of alternative specifications for the number of gross and net inflows in Table 5. Our first test tackles the fact that we have two observations for each country pair and year. Since positive net inflows from country $i$ to $k$ equal negative net inflows from country $k$ to $i$, we include each country pair only once. Therefore, we drop all country pairs with negative net inflows; when net inflows are zero we randomly drop one of the country pairs. The results in Column (1) based on 1224 country-pair-year observations show that our results do not change materially, only stock market returns are no longer statistically significant. 
Table 5

Robustness tests.

\begin{tabular}{|c|c|c|c|c|c|c|c|}
\hline & \multirow{3}{*}{$\begin{array}{l}(1) \\
1 \text { obs per country-pair }\end{array}$} & (2) & (3) & $(4)$ & (5) & (6) & (7) \\
\hline & & \multicolumn{2}{|c|}{ Without US and UK } & \multicolumn{2}{|l|}{ With selection stage } & \multicolumn{2}{|c|}{ With dynamic responses } \\
\hline & & Gross inflows & Net inflows & Gross inflows & Net inflows & Gross inflows & Net inflows \\
\hline Capitalization & $-0.241(0.040)^{* * *}$ & $0.117(0.032)^{* * * *}$ & $-0.276(0.044)^{* * *}$ & $0.047(0.028)^{*}$ & $-0.300(0.041)^{* * *}$ & $0.117(0.067)^{*}$ & $-0.306(0.059)^{* * *}$ \\
\hline Patents & $-0.002(0.007)$ & $0.044(0.009)^{* * *}$ & $-0.004(0.008)$ & $0.013(0.007)^{*}$ & $0.010(0.007)$ & $0.028(0.019)$ & $0.008(0.011)$ \\
\hline Expected growth & $6.400(2.330)^{* * *}$ & $-3.797(1.932)^{* *}$ & $6.902(2.154)^{* * *}$ & $3.348(1.754)^{*}$ & $7.465(2.116)^{* * *}$ & $-0.157(3.126)$ & $13.421(2.628)^{* * *}$ \\
\hline Returns & $0.127(0.098)$ & $0.067(0.099)$ & $0.138(0.071)^{*}$ & $0.102(0.061)^{*}$ & $0.164(0.091)^{*}$ & $-0.250(0.131)^{*}$ & $-0.013(0.159)$ \\
\hline Lack funds & $-0.076(0.047)$ & $-0.079(0.038)^{* *}$ & $-0.097(0.043)^{* *}$ & $-0.125(0.038)^{* * *}$ & $-0.065(0.039)^{*}$ & $-0.012(0.046)$ & $-0.036(0.050)$ \\
\hline Excess funds & $0.125(0.052)^{* *}$ & $-0.055(0.050)$ & $0.186(0.054)^{* * *}$ & $-0.080(0.036)^{* *}$ & $0.193(0.042)^{* * *}$ & $-0.030(0.060)$ & $0.111(0.057)^{*}$ \\
\hline $\begin{array}{l}\text { VC-supply indicator } \\
\text { Mills ratio }\end{array}$ & $-0.168(0.049)^{* * *}$ & $0.108(0.040)^{* * * *}$ & $-0.070(0.041)^{*}$ & $\begin{array}{l}0.074(0.039)^{*} \\
-0.361(0.024)^{* * * *}\end{array}$ & $\begin{array}{l}-0.075(0.041)^{*} \\
0.037(0.018)^{* *}\end{array}$ & $0.146(0.070)^{* *}$ & $-0.107(0.058)^{*}$ \\
\hline Lag dependent variable & & & & & & $0.123(0.048)^{* *}$ & $0.163(0.045)^{* * *}$ \\
\hline No. of observations & 1224 & 1890 & 1890 & 2448 & 2448 & 2176 & 2176 \\
\hline F-test [Wald-test] & $9.9 * * *$ & $29.0^{* * *}$ & $13.4^{* * *}$ & {$\left[1958.6^{* * *}\right]$} & {$\left[520.8^{* * *}\right]$} & $4.9^{* * * *}$ & $9.0^{* * * *}$ \\
\hline Adjusted $R^{2}$ & 0.17 & 0.25 & 0.16 & 0.41 & 0.18 & & \\
\hline Hansen ( $p$-value) & & & & & & 0.23 & 0.77 \\
\hline Ar1 ( $p$-value) & & & & & & 0.00 & 0.00 \\
\hline Ar2 ( $p$-value) & & & & & & 0.77 & 0.55 \\
\hline Ar3 ( $p$-value) & & & & & & 0.95 & 0.71 \\
\hline
\end{tabular}

Estimation results for gross and net inflows for the period 2000-2008. The model in Column (1) is given as follows: $\mathrm{NCB}_{i k t}=\gamma_{0}+\gamma_{1}$ Capitalization $_{(i t-1)}+\gamma_{2}$ Patents $_{(i t-1)}+\gamma_{3}$ Expected growth $_{i t}+\gamma_{4}$ Returns $_{(i t-1)}+\gamma_{5}$ Lack funds $_{(i t-1)}+\gamma_{6}$ Excess funds $_{(i t-1)}+\gamma_{7}$ VC-supply indicator $_{(i t-1)}+b_{i k t}$, where NCB denotes net inflows defined as investments attracted by country $i$ from $k$ minus investments originated by $i$ in $k$ in year $t$. RHS variables are defined in Table 2 . In Column (1), only one observation for each country pair is included. In Columns (2)-(3) observations from the United Kingdom and the United States are excluded from the estimations. In Columns (1)-(3) White (1980)-heteroscedasticityconsistent standard errors are given in parentheses. In Columns (4)-(5) the inverse Mills ratio from a first-stage regression (whether or not any cross-border investments are observed in either direction) is included. The first-stage model (results not depicted) includes the same RHS variables plus dummy variables for the same law tradition and language, and the geographical distance between the two countries. Bootstrapped standard errors with 150 replications are presented in parentheses. In Columns (6)-(7), results come from Blundell and Bond (1998)-GMM estimations with Windmeijer's (2005) corrected standard errors in parentheses. The lagged dependent variable is instrumented. ${ }^{* * *}$, **, and * denote significance at the 1,5 , and 10 percent level, respectively. 
Next, we exclude the United States and the United Kingdom from the sample because these economies are much more market based than the rest of our sample in terms of stock market capitalization as well as turnover (e.g., Beck and Levine, 2002) and because venture capital industries in these countries differ from the other countries in size and structure. Moreover, the United Kingdom played a specific role in the venture capital and private equity internationalization process in the past. US investors, such as Advent, General Atlantic, and Benchmark, used the United Kingdom to systematically enter European industries in the boom phase at the end of the 1990s (Hardymon et al., 2003). Since syndicating with domestic investors played an important role, the expertise brought from the United States to the United Kingdom may have changed the business model of UK venture capitalists. Most of our estimation results (see Columns (2) and (3)), however, do not depend much on whether or not the United States and the United Kingdom are included in the analyses.

Our third robustness test puts particular emphasis on those country pairs for which no transaction occurs in either direction. For gross inflows, 1317 of the 2448 country-pair-year observations are equal to zero since venture capitalists located in country $k$ do not invest in portfolio companies located in country $i$ in the particular year. For net inflows, 1016 of the 2448 country-pair-year observations are equal to zero since no cross-border transaction occurs in either direction. A two-step selection model (Heckman, 1979) helps us to account for the possibility that the existence and the size of cross-border flows are driven by different processes. In the selection regression we estimate the inverse Mills ratio, which we then include as an additional RHS variable in the outcome regression. Standard errors are bootstrapped with 150 replications to take into account that the inverse Mills ratio is a generated regressor. In the selection regression the dependent variable is equal to one when we observe crossborder flows between country $i$ and $k$ in at least one direction, and zero otherwise. In this regression we use economic factors, country and year dummy variables and three distinct measures as RHS variables to capture the cultural and geographical proximity between countries $i$ and $k::^{7}$ the log of the geographical distance between the two countries, a dummy variable equal to one when the two countries share the same legal tradition as classified by La Porta et al. (1998), and a dummy variable equal to one when the same language is spoken in the two countries. Columns (4) and (5) reveal a selection bias in both gross and net inflows, since the coefficients on the inverse Mills ratios are statistically significant. For gross inflows, the coefficients on capitalization, patent counts, excess funds, and the VC-supply indicator keep their signs (but the coefficients are of a lower magnitude) and they are significant at conventional levels. Interestingly and noteworthy, when we control for a selection bias, expected growth and returns affect gross inflows significantly in a positive way. For net inflows, we see all previous results confirmed. Thus, even when we control for a selection bias, higher capitalization and a more favorable environment for venture capital intermediation increase gross inflows and decrease net inflows.

Our final robustness check deals with dynamic responses in gross and net inflows, which we expect for the following reasons. Countries that have more promising investment opportunities than other countries and therefore attract more foreign venture capitalists in one year, are more likely to also offer more promising investment opportunities in the following year. Herding behavior among venture capitalists might be another reason that induces dynamic responses in gross and net inflows. In addition, venture capital funds are often specialized, i.e. they focus on investments in one country or one region. Since this specialization is a part of their fund strategy, which they have bindingly declared towards their limited partners, switching to other countries or regions is impossible or at least very costly from the fund's perspective. However, even funds that are not bindingly specialized may exhibit a certain persistence in their country portfolio structure by continuing to invest in those countries in which they have built up know-how and experience. Certainly, venture capitalists may gain experience in new regions and raise funds designed for investments in these regions; this, however, takes time. Thus, learning may hinder venture capitalists to fully and instantly equalize expected return differences between countries. Finally, some of the persistence may also result from the fact that venture

\footnotetext{
7 These measures have formerly been employed in the literature on international capital flows (e.g., Barron and Valev, 2000; Portes et al., 2001; Portes and Rey, 2005 for equity flows; Buch, 2003 for banks' foreign asset holdings, and Buch and DeLong, 2004 for cross-border bank mergers).
} 
capitalists typically provide capital in stages and thus repeatedly invest in the same portfolio company (and hence in the same country).

To test for dynamic responses, we extend the models by including a lag of the dependent variable and by modeling a fixed effect for each of the 272 country pairs. The fixed effects for country pairs resolve problems otherwise arising from time-invariant heterogeneity in bilateral country relationships, which might influence gross and net flows, such as geographical distance, and cultural as well as institutional differences. We use the dynamic panel-data estimator proposed by Blundell and Bond (1998), and a finite sample correction proposed by Windmeijer (2005). In Columns (6) and (7) the tests on overidentifying restrictions and autocorrelations fully verify this modeling approach. The lagged dependent variables have positive coefficients which are statistically significant for both gross and net inflows. Thus, higher gross and net inflows in one year lead to higher inflows in the following year. Most of our economic factors (in particular in the net inflow regression) retain their signs and significance levels in this dynamic model specification and their coefficients' levels resemble those in the static specification presented in Table 4.

\subsection{Country-level analysis}

In addition to country pairs, we also aggregate the data to country levels to investigate if economic factors shape gross and net flows differently. Unlike the country-pair sample, this sample does not suffer from censoring problems. Therefore, we hope to gain additional insights into how expected growth is related to gross inflows, which, in the country-pair sample, only had a significantly positive effect when we controlled for a selection bias. Moreover, the country-level sample allows us to investigate how economic factors shape not only cross-border, but also domestic investments. The drawback of using the country-level sample is the small number of observations, which reduces to $17 \times 9=153$ country-year observations. This number is too small to investigate dynamic responses. In addition, several country dummy variables are too strongly correlated with our economic factors, so that country effects cannot be controlled for. We aggregate (the number and volume of) domestic investments, gross inflows, gross outflows, and net inflows for each country $i$ and each year $t$. We normalize the investments by GDP and use a log transformation, except for net inflows since they are the difference between normalized and log-transformed inflows and outflows.

Table 6 displays results for investment number (Panel a) and investment volume (Panel b). Column (1) depicts results on domestic investments. A higher patent count comes along with more domestic investments. When the patent count increases by one-standard deviation, the volume of domestic investments (normalized by GDP and log-transformed), which is 6.08 on average, increases by 0.27 . Higher expected growth increases the number of domestic investments, but it lacks significance for the volume. When expected growth increases by one-standard deviation, the number of domestic investments, which is 4.21 on average, increases by 0.24 . Finally, countries with higher VC-supply indicators have a higher number of domestic investments.

Our results from the country sample for gross inflows, gross outflows and net inflows are broadly in line with our findings from the country-pair sample. Capitalization significantly increases the number and volume of gross inflows and outflows, but it significantly decreases net inflows. When capitalization increases by one-standard deviation, the number of gross inflows, which is 4.13 on average, rises by 0.17 , the number of gross outflows, which is 3.82 on average, increases by 0.46 , and the number of net inflows, which is -0.11 on average (which is different from zero due to the transformation) with a standard deviation of 0.85 , decreases by 0.29 . Higher expected growth attracts foreign venture capitalists to invest in this country, although this effect is only significant for the investment number. At the same time venture capitalists located in a country with higher expected growth invest significantly less abroad, although this effect is only significant for investment volume. These effects may indicate that countries with greater expected growth are likely to provide more investment opportunities and therefore attract more foreign venture capitalists and induce venture capitalists located in these countries to invest less often abroad. When the aggregate investments substantially exceeded fundraising in the previous three years, countries originate a lower number of deals abroad. We do not find such an effect for deal volume, which might indicate that with a lack of funds venture capitalists concentrate on large deals and ignore small investment opportunities outside their home countries. 
Table 6

Domestic investments and cross-border flows.

\begin{tabular}{|c|c|c|c|c|}
\hline & Domestic investments & Gross inflows & Gross outflows & Net inflows \\
\hline \multicolumn{5}{|c|}{ Panel a - Investment number } \\
\hline Capitalization & $0.024(0.142)$ & $0.273(0.093)^{* * * *}$ & $0.754(0.122)^{* * *}$ & $-0.480(0.133)^{* * *}$ \\
\hline Patents & $0.071(0.022)^{* * *}$ & $-0.033(0.023)$ & $-0.037(0.030)$ & $0.004(0.028)$ \\
\hline Expected growth & $25.911(5.957)^{* * *}$ & $21.567(6.656)^{* * *}$ & $-7.376(10.594)$ & $28.943(11.058)^{* * *}$ \\
\hline Returns & $-0.022(0.258)$ & $0.240(0.201)$ & $0.030(0.246)$ & $0.210(0.300)$ \\
\hline Lack funds & $-0.213(0.149)$ & $-0.350(0.123)^{* * *}$ & $-0.622(0.271)^{* *}$ & $0.272(0.268)$ \\
\hline Excess funds & $0.149(0.153)$ & $-0.197(0.143)$ & $-0.271(0.182)$ & $0.074(0.141)$ \\
\hline VC-supply indicator & $0.351(0.130)^{* * *}$ & $0.455(0.130)^{* * *}$ & $1.007(0.188)^{* * *}$ & $-0.552(0.178)^{* * *}$ \\
\hline No. of observations & 153 & 153 & 153 & 153 \\
\hline$F$-test & $7.0^{* * *}$ & $10.1^{* * *}$ & $11.7^{* * *}$ & $6.7^{* * *}$ \\
\hline Adjusted $R^{2}$ & 0.25 & 0.30 & 0.42 & 0.21 \\
\hline \multicolumn{5}{|c|}{ Panel $b$ - Investment volume } \\
\hline Capitalization & $0.133(0.186)$ & $0.278(0.136)^{* *}$ & $0.911(0.163)^{* * *}$ & $-0.633(0.190)^{* * *}$ \\
\hline Patents & $0.108(0.033)^{* * *}$ & $-0.023(0.032)$ & $-0.023(0.040)$ & $0.000(0.047)$ \\
\hline Expected growth & $1.262(11.278)$ & $11.085(9.883)$ & $-30.475(16.000)^{*}$ & $41.560(17.077)^{* *}$ \\
\hline Returns & $0.447(0.334)$ & $0.438(0.248)^{*}$ & $0.370(0.437)$ & $0.067(0.477)$ \\
\hline Lack funds & $0.141(0.240)$ & $0.251(0.240)$ & $-0.242(0.397)$ & $0.493(0.410)$ \\
\hline Excess funds & $0.177(0.180)$ & $-0.334(0.157)^{* *}$ & $-0.075(0.214)$ & $-0.259(0.219)$ \\
\hline VC-supply indicator & $0.090(0.231)$ & $0.204(0.191)$ & $1.510(0.303)^{* * * *}$ & $-1.306(0.297)^{* * *}$ \\
\hline No. of observations & 153 & 153 & 153 & 153 \\
\hline$F$-test & $2.7^{* * * *}$ & $1.9^{*}$ & $8.8^{* * *}$ & $6.7^{* * *}$ \\
\hline Adjusted $R^{2}$ & 0.10 & 0.04 & 0.34 & 0.22 \\
\hline
\end{tabular}

Estimation results are from OLS regressions based on 17 countries and the period 2000-2008. The model looks like: $y_{i t}=\gamma_{0}+$ $\gamma_{1}$ Capitalization $_{(i t-1)}+\gamma_{2}$ Patents $\left._{(i t-1}+\right) \gamma_{3}$ Expected growth $_{i t}+\gamma_{4}$ Returns $_{(i t-1)}+\gamma_{5}$ Lack funds $_{(i t-1)}+\gamma_{6}$ Excess funds $_{(i t-1)}+$ $\gamma_{7}$ VC-supply indicator ${ }_{(i t-1)}+c_{i t}$, where $y$ is either domestic investments (the venture capitalist and portfolio company are located in country $i$ ), or gross inflows (the portfolio company but not the venture capitalist is located in country $i$ ), or gross outflows (the venture capitalist but not the portfolio company is located in country $i$ ), or net inflows defined as gross inflows minus gross outflows. By definition, the coefficients on economic factors for net outflows (not depicted) are equal to minus the coefficients for net inflows. Domestic investments, gross inflows and outflows are normalized by GDP and log-transformed. All RHS variables are defined in Table 2. Year dummy variables are included. White (1980)-heteroscedasticity-consistent standard errors are given in parentheses. ${ }^{* * *},{ }^{* *}$, and ${ }^{*}$ denote significance at the 1,5 , and 10 percent level, respectively.

Finally, and also in line with our previous findings, a higher VC-supply indicator leads to higher gross inflows and gross outflows, but to lower net inflows.

\section{Summary and concluding remarks}

We use a dataset of venture capital investments in European and North American countries to investigate whether economic factors shape gross and net cross-border venture capital flows differently. We find that most economic factors shape gross and net outflows in a similar way. For instance, higher stock market capitalization and a more favorable environment for venture capital intermediation entail higher gross and net outflows, while higher expected growth goes hand in hand with lower gross and net outflows.

While economic factors affect gross and net outflows in a similar way, we identify two economic factors that shape a country's gross and net inflows differently: stock market capitalization and the tax and legal environment for venture capital intermediation. A higher stock market capitalization entails higher gross inflows but lower net inflows. These findings are not at all contradictory. They may indicate that capitalization is related to both demand and supply of venture capital. Higher capitalization leads to a higher demand for venture capital. Many venture capital financed deals offer syndication opportunities for foreign venture capitalists such that this country attracts a great amount of capital from abroad (gross inflows). At the same time, higher capitalization leads to higher venture capital supply and this country originates many deals abroad (gross outflows). These gross outflows respond more strongly to capitalization than gross inflows, which gives rise to the negative relation 
between capitalization and net inflows. The tax and legal environment for venture capital intermediation is also differently related to gross and net inflows. A poorer environment for venture capital intermediation goes hand in hand with lower gross inflows, but it generates higher net inflows. This finding may lend support to the hypothesis that venture capitalists located in countries with attractive tax and legal environments for venture capital intermediation are attracted by investment opportunities in countries with less favorable tax and legal conditions for venture capital intermediation. Other economic factors, such as expected growth, affect gross and net inflows in a similar way.

For policy makers who aim at establishing viable venture capital industries, our research analyses offer important insights since our results suggest that economic factors affect gross cross-border inflows and net cross-border inflows in a different way. From a governmental perspective, net inflows are more relevant than gross inflows because they provide insights into how much more venture capital finance companies from this country attract from other countries than venture capitalists from this country originate abroad, while gross inflows ignore that venture capitalists located in one country also invest in other countries. Thus, if policy fails to create a viable tax and legal environment for venture capital intermediation, foreign venture capitalists may step in and offer funding to venture capital-seeking companies. Indeed, our findings may indicate that net cross-border inflows partly compensate for a low availability of venture capital finance provided by local venture capitalists. This might sound like good news. However, the venture capitalists' locational decisions also depend on a viable environment for venture capital intermediation. A poor environment may incentivize managers originally located in a country to move or set up their fund and management company in another country with a more favorable environment for venture capital intermediation. Thus, our findings might also be the consequence of venture capitalists' locational decisions.

\section{Acknowledgments}

The current version has benefited from comments by an anonymous referee, William Megginson, Reint Gropp, and participants at the VHB meeting in Berlin, the FMA European conference in Prague, the annual meeting of the European Economic Association in Milan, and the ESSEC private equity conference in Paris. Jonas Vogt provided excellent research assistance. The authors are indebted to Bureau van Dijk Electronic Publishing (BvDEP) for providing data. Financial support from the 7th Research Framework Programme (FP7) of the European Commission is gratefully acknowledged (Project title: Financing Entrepreneurial Ventures in Europe: impact on innovation, employment growth, and competitiveness, Grant Agreement Number 217485).

\section{References}

Abdesselam, R., Cieply, S., Le Nadant, A.-L., 2008. Are corporate governance systems typologies relevant? Evidence from European transfers of ownership rights. Corporate Ownership \& Control 5 (2), 87-99.

Aizenman, J., Kendall, J., 2008. The internationalization of venture capital and private equity. NBER Working Paper 14344.

Allen, F., Song, W., 2005. Venture capital and corporate governance. Wharton University Working Paper.

Amit, R., Brander, J., Zott, C., 1998. Why do venture capital firms exist? Theory and Canadian evidence. Journal of Business Venturing 13, 441-466.

Armour, J., Cumming, D., 2006. The legislative road to Silicon Valley. Oxford Economic Papers 58 (4), 596-635.

Barron, J.M., Valev, N.T., 2000. International lending by U.S. banks. Journal of Money, Credit and Banking 32 (3), $357-381$.

Bascha, A., Walz, U., 2002. Convertible securities and optimal exit decisions in venture capital finance. Journal of Corporate Finance 7 (3), 285-306.

Beck, T., Levine, R., 2002. Industry growth and capital allocation: does having a market- or bank-based system matter? Journal of Financial Economics 64 (2), 147-180.

Beuselinck, C., Deloof, M., Manigart, S., 2009. Private equity involvement and earnings quality. Journal of Business Finance and Accounting 26 (5-6), 587-615.

Black, B.S., Gilson, R.J., 1998. Venture capital and the structure of capital markets: banks versus stock markets. Journal of Financial Economics 47 (3), 243-277.

Bloom, N., Sadun, R., Van Reenen, J., 2009. Do private equity owned firms have better management practices? In: Gurung, A., Lerner, J. (Eds.), The Global Economic Impact of Private Equity Report 2009 Globalization of Alternative Investments, vol. 2, pp. 1-24.

Blundell, R.W., Bond, S.R., 1998. Initial conditions and moment restrictions in dynamic panel data models. Journal of Econometrics 87, 29-52.

Bottazzi, L., Da Rin, M., Hellmann, T., 2009. What role of legal systems in financial intermediation? Theory and evidence. Journal of Financial Intermediation 18, 559-598. 
Brav, A., Brav, O., Jiang, W., 2009. The choice of going public and going private: evidence from UK. Working Paper.

Bruner, R.F., Chaplinsky, S.J., 2002. Practices of Active Private Equity Firms in Latin America. Available at SSRN: http://ssrn.com/ abstract $=909702$.

Buch, C.M., 2003. Information or regulation: what drives the international activities of commercial banks? Journal of Money, Credit and Banking 35 (6), 851-869.

Buch, C.M., DeLong, G., 2004. Cross-border bank mergers: what lures the rare animal? Journal of Banking and Finance 28 (9), 2077-2102.

Chen, H., Gompers, P., Kovner, A., Lerner, J., 2010. Buy local? The geography of venture capital. Journal of Urban Economics 67 (1), 90-102.

Cumming, D., Johan, S., 2007. Regulatory harmonization and the development of private equity markets. Journal of Banking and Finance 31 (10), 3218-3250.

Cumming, D., MacIntosh, J.G., 2006. Crowding out private equity: Canadian evidence. Journal of Business Venturing 21, 569-609.

Cumming, D., Walz, U., 2010. Private equity returns and disclosure around the world. Journal of International Business Studies 41 (4), 727-754.

Cumming, D., Schmidt, D., Walz, U., 2010. Legality and venture governance around the world. Journal of Business Venturing 25 (1), 54-72.

Da Rin, M., Nicodano, G., Sembenelli, A., 2006. Public policy and the creation of active venture capital markets. Journal of Public Economics 90, 1699-1723.

Dahl, D., Shrieves, R.E., 1999. The extension of international credit by US banks: a disaggregated analysis, 1988-1994. Journal of International Money and Finance 18, 153-167.

Dai, N., Hoje, J., Kassicieh, S. Cross-border venture capital investments in Asia: selection and exit performance. Journal of Business Venturing, in press.

Devigne, D., Vanacker, T.R., Manigart, S., Paeleman, I., 2011. Cross-border venture capital and the development of portfolio companies. Available at SSRN: http://ssrn.com/abstract=173466.

Dixit, A., Jayaraman, N., 2001. Internationalization strategies of private equity firms. Journal of Private Equity 5 (1), $40-54$.

EVCA (European Private Equity and Venture Capital Association), 2003. Benchmarking tax and legal environments report. Zaventem, Belgium.

EVCA (European Private Equity and Venture Capital Association), 2004. Benchmarking tax and legal environments report. Zaventem, Belgium.

EVCA (European Private Equity and Venture Capital Association), 2006. Benchmarking tax and legal environments report. Zaventem, Belgium.

Gompers, P.A., 1996. Grandstanding in the venture capital industry. Journal of Financial Economics 42 (19), 133-156.

Gompers, P.A., Lerner, J., 1998. What drives venture capital fundraising? Brooking Papers on Economic Activity - Microeconomics, 149-192.

Goossens, L., Manigart, S., Meuleman, M., 2008. The change in ownership after a buyout: impact on performance. Journal of Private Equity 12 (1), 31-41.

Groh, P.G., von Lichtenstein, H., 2009. How attractive is central Eastern Europe for risk capital investors? Journal of International Money and Finance 28, 625-647.

Guler, I., Guillén, M., 2010a. Home-country networks and foreign expansion: evidence from the venture capital industry. Academy of Management Journal 53 (2), 390-410.

Guler, I., Guillén, M., 2010b. Knowledge, institutions and organizational growth: the internationalization of U.S. venture capital firms. Journal of International Business Studies 41, 185-205.

Hardymon, F., Lerner, J., Leamon, A., 2003. Accel Partners' European Lunch. HBS Case 9-803-021. Harvard Business School, Boston, MA.

Heckman, J.J., 1979. Sample selection bias as a specification error. Econometrica 47 (1), 153-161.

Jeng, L.A., Wells, P.C., 2000. The determinants of venture capital funding: evidence across countries. Journal of Corporate Finance 6 (3), 241-289.

Kaplan, S., Martel, F., Strömberg, P., 2007. How do legal differences and experience affect financial contracts. Journal of Financial Intermediation 16 (3), 273-311.

Keuschnigg, C., Nielsen, S.B., 2002. Tax policy, venture capital, and entrepreneurship. Journal of Public Economics 87, 175-203.

Keuschnigg, C., Nielsen, S.B., 2004. Start-ups, venture capitalists, and the capital gains tax. Journal of Public Economics 88, 1011-1042.

La Porta, R., Lopez-de-Silanes, F., Shleifer, A., Vishny, R.W., 1998. Law and finance. Journal of Political Economy 106 (6), $1113-1155$

Lerner, J., Schoar, A., 2004. Transaction structures in the developing world: evidence from private equity. NBER Working Paper 10348.

Mäkelä, M.M., Maula, M., 2006. Interorganizational commitment in syndicated cross-border venture capital investments. Entrepreneurship: Theory and Practice 30 (2), 273-298.

Manigart, S., Lockett, A., Meuleman, M., Wright, M., Bruining, H., Landström, H., Desbrières, P., Hommel, U., 2006. The syndication decision of venture capital investments. Entrepreneurship: Theory and Practice 30 (2), 131-153.

Portes, R., Rey, H., 2005. The determinants of cross-border equity flows. Journal of International Economics 65 (2), $269-296$.

Portes, R., Rey, H., Oh, Y., 2001. Information and capital flows: the determinants of transactions in financial assets. European Economic Review 45 (4-6), 783-796.

Poterba, J.M., 1989. Venture capital and capital gains taxation. Tax Policy and the Economy 3, 47-67.

Prijcker, S. De, Manigart, S., Wright, M., De Maeseneire, W., 2009. The influence of international human capital and international network relationships on the cross-border investment behaviour of private equity firms. Ghent University. Working Paper $2009 / 597$.

Ribeiro, L.L., De Carvalho, A.G., 2008. Private equity and venture capital in an emerging economy: evidence from Brazil. Venture Capital 10 (2), 111-126. 
Romain, A., van Pottelsberghe, B., 2004. The determinants of venture capital: additional evidence. Discussion Paper Series 1: Studies of the Economic Research Centre 19, Deutsche Bundesbank.

Schertler, A., Tykvová, T., 2011. Venture capital and internationalization. International Business Review 20, 423-439.

Strömberg, P., 2009. The economic and social impact of private equity in Europe: summary of research findings. Available at SSRN: http://ssrn.com/abstract=1429322.

Ueda, M., Hirukawa, M., 2008. Venture capital and innovation: which is first? Available at SSRN: http://ssrn.com/ abstract $=1242698$.

White, H., 1980. A heteroskedasticity-consistent covariance matrix estimator and a direct test for heteroskedasticity. Econometrica 48 (4), 817-838.

Windmeijer, F., 2005. A finite sample correction for the variance of linear efficient two-step GMM estimators. Journal of Econometrics 126 (1), 25-51.

Wright, M., Pruthi, S., Lockett, A., 2005. International venture capital research: from cross country comparisons to crossing countries. International Journal of Management Reviews 7 (3), 135-166. 